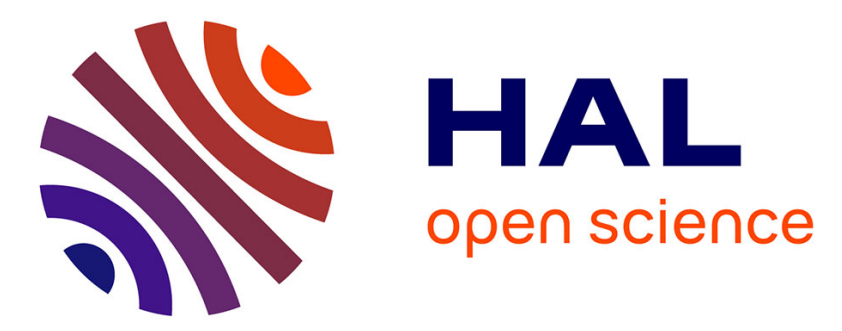

\title{
From orogenic collapse to rifting: A case study of the northern Porcupine Basin, offshore Ireland
}

Cédric Bulois, Manuel Pubellier, Nicolas Chamot-Rooke, Louise Watremez

\section{To cite this version:}

Cédric Bulois, Manuel Pubellier, Nicolas Chamot-Rooke, Louise Watremez. From orogenic collapse to rifting: A case study of the northern Porcupine Basin, offshore Ireland. Journal of Structural Geology, 2018, 114, pp.139-162. 10.1016/j.jsg.2018.06.021 . hal-02323760

\section{HAL Id: hal-02323760 \\ https://hal.science/hal-02323760}

Submitted on 23 Oct 2019

HAL is a multi-disciplinary open access archive for the deposit and dissemination of scientific research documents, whether they are published or not. The documents may come from teaching and research institutions in France or abroad, or from public or private research centers.
L'archive ouverte pluridisciplinaire $\mathbf{H A L}$, est destinée au dépôt et à la diffusion de documents scientifiques de niveau recherche, publiés ou non, émanant des établissements d'enseignement et de recherche français ou étrangers, des laboratoires publics ou privés. 


\title{
From orogenic collapse to rifting: A case study of the northern Porcupine Basin, offshore Ireland
}

\author{
Cédric Bulois ${ }^{\mathrm{a}, \text { b, c, * }, \text { Manuel Pubellier }}{ }^{\mathrm{a}}$, Nicolas Chamot-Rooke ${ }^{\mathrm{a}}$, Louise Watremez ${ }^{\mathrm{d}}$ \\ a Laboratoire de Géologie, CNRS/UMR 8538, Ecole Normale Supérieure, PSL Research University, 24 Rue Lhomond, 75005 Paris, France \\ b Laboratoire Domaines Océaniques, CNRS/UMR 6538, Institut Européen de la Mer, Technopôle Brest Iroise, Place Nicolas Copernic, F-29280 Plouzané, France \\ ${ }^{c}$ School of Earth Sciences, University College Dublin, Belfield, Dublin 4, Ireland \\ ${ }^{\mathrm{d}}$ Univ. Lille, CNRS, Univ. Littoral Côte d'Opale, UMR 8187, Laboratoire d'Océanologie et de Géosciences, F-59000 Lille, France
}

\section{ARTICLE INFO}

\section{Keywords:}

Orogenic collapse

Long-lasting polyphased rifting

Fault reactivation

Rift propagator

Porcupine basin

Continental margin

\begin{abstract}
A B S T R A C T
Offshore Ireland, the North Atlantic opening is generally interpreted as successive, 10-to-15-Myr-long, rifting events during the Mesozoic. However, their interaction is poorly documented in terms of structural inheritance and fault reactivation. From extensive seismic and well data in the northern Porcupine Basin, we show that extension actually evolved over an abnormal period of ca. 220 Myrs with overlapping tectonic stages that, all together, reflect the Irish Atlantic Margin construction from the Palaeozoic.

During the Carboniferous, extension initiated throughout the Variscan and Caledonian thickened crusts and controlled the deposition of generally slightly-tilted, continental clastics. Two subsequent rifting events, during the Triassic-Lower Jurassic and Upper-Jurassic-Lower Cretaceous, controlled shallow-to-deep marine sedimentation in separated sub-basins that progressively widen and connect once extension localised along bounding faults.

We propose that extensional tectonics, first controlled by a general orogenic collapse reflecting an early stage of stretching, is then followed by several rifting periods that ultimately evolved toward the hyper-thinning of the margin and shaped an aborted rift propagator. This evolution is due to pre-existing orogenic-related structures and boundary conditions variations. Such a continuum of deformation, although pulsed, implies varying structural interactions of crustal scale that are often recorded in syn-tectonic sediments.
\end{abstract}

\section{Introduction}

The continental lithosphere deforms according to a number of geological events that successively open and close oceanic domains according to the Wilson Cycle concept (Burke and Dewey, 1974). From this theoretical view, the divergence of continental masses forms extensional systems on top of old orogenic features within a continuum of deformation during which rift basins progressively evolve to passive margin settings. Also, extension is often defined from the unique recognition of syn- and postrift unconformities that bound characteristic growth-faulting sedimentary sequences (Grow et al., 1983; Badley et al., 1984, 1988; Frostick and Steel, 1993; Prosser, 1993; Purser and Bosence, 1998). Modern data show that deformation is more complex, especially in the case of longstanding extensional history during which basins may encompass several overlapping rifting events. This is partic- ularly well observed along the North Atlantic margins (e.g. Ziegler, 1988 \& 1990; Tankard and Balkwill, 1989; Doré et al., 1999; Williams et al., 1999; Stoker et al., 2017) where basin geometries and sedimentary infills are influenced by the early basement framework or previous rifted structures (e.g. Bartholomew et al., 1993; Doré et al., 1997; Roberts et al., 1999). Nevertheless, the tectonic relationships between the various tectonic phases are not fully resolved in terms of nature, significance and timing and their integration within an overall hyper-thinning scenario leading to passive margin setting remains uncertain.

Offshore west of Ireland, the Porcupine Basin (Fig. 1) represents a typical example of such polyphased relationships between basement and shallower rifted structures. The basin is superimposed on top of two Palaeozoic orogenic belts formed during the Pangaea amalgamation and now reveals a highly-stretched continental crust covered by up to $10 \mathrm{~km}$ of sediments of Upper Palaeozoic, Mesozoic and Cenozoic

\footnotetext{
* Corresponding author. Laboratoire de Géologie, CNRS/UMR 8538, Ecole Normale Supérieure, PSL Research University, 24 Rue Lhomond, 75005 Paris, France.

Email address: bulois@geologie.ens.fr (C. Bulois)
} 


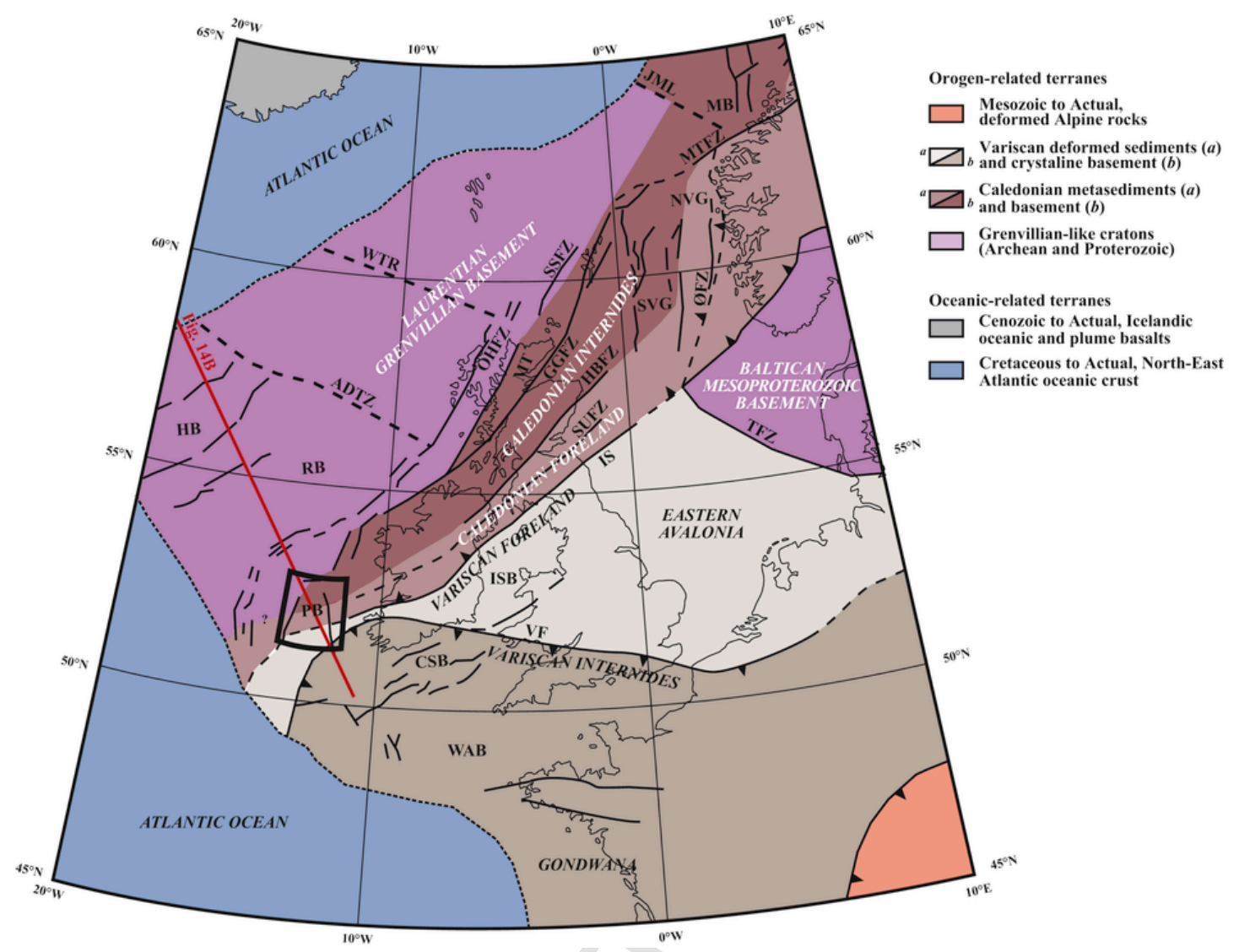

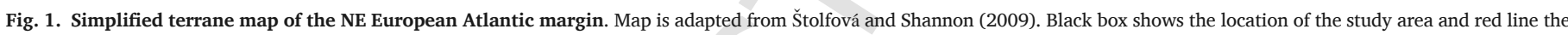

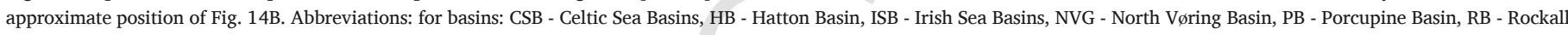

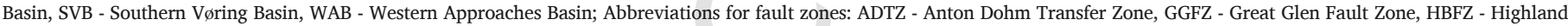

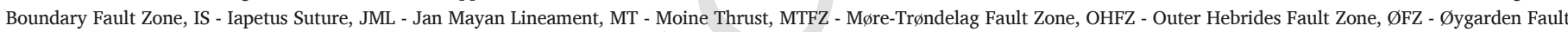

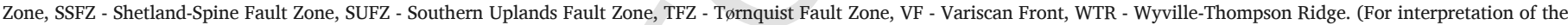
references to colour in this figure legend, the reader is referred to the Web version of this article.)

sediments and several crosscutting Cretaceous and Cenozoic igneous bodies (Fig. 2, e.g. Naylor et al., 2002; Naylor and Shannon, 2009 \& 2011; Gagnevin et al., 2017). It formed during several so-called rifting events that have a variable magnitude at the scale of the basin. The main rifting event, of Upper Jurassic age, formed characteristic rotational fault-blocks sealed by the Base Cretaceous Unconformity (e.g. MacDonald et al., 1987; Sinclair et al., 1994; Robinson and Canham, 2001; Jones and Underhill, 2011). Several other thickening phases have been suggested in the Permo-Triassic (Naylor et al., 2002; Štolfová and Shannon, 2009) and Cretaceous (Naylor and Anstey, 1987; Moore, 1992). This extensional evolution remains however unclear in terms of fault geometries and reactivation mechanisms, due to poor seismic resolution and the full consideration of new crustal extension concepts.

Herein, we specifically investigate the Palaeozoic and Mesozoic extensional history of the northern part of the Porcupine region to highlight tectonic interactions between the various extensional events. Our study is based on original interpretation of $2 \mathrm{D}$ and 3D seismic data (19237 km and $324 \mathrm{~km}^{2}$ respectively) tied to twenty six exploration wells (Fig. 1). The overall dataset was analysed using classical seismic stratigraphic methods (Mitchum et al., 1977) and correlated to lithological information by using traditional gamma-ray and sonic responses (Rider, 1990; Serra, 1995; Reading, 2007). We also further constrained the age and depositional environments by using lithologies and biostratigraphic records provided in well reports, as well as available cores and cuttings. Sedimentary megasequences are mapped regionally and their genetics is discussed according to the formation of the Irish Atlantic Margin. They particularly demonstrate the influence of early structural frameworks on the construction of a wide Atlantic-type passive margin that acquired a certain tectonic independence over time.

\section{Structural framework of the Porcupine region and aims of this study}

As part of the Irish Atlantic Margin, the Porcupine Basin opened through the Caledonides and Variscides fold and thrust belts (Fig. 1). Repeated extensional events (Doré et al., 1999; Stoker et al., 2017) produced an hyper-stretched, 20-to-7.5-km thick and sometimes thinner, basement, overlain by up to $10 \mathrm{~km}$ of Upper Palaeozoic to Cenozoic sediments, and flanked by 30-to-35-km-thick and 25-to-28-km thick continental crusts (e.g. Buckley and Bailey, 1975; Masson et al., 1985; Makris et al., 1988; Jacob et al., 1995; Johnson et al., 2001; O'Reilly et al., 2006; Watremez et al., 2016; Prada et al., 2017). The rifting led to combined stretching factors increasing southward (White et al., 1992; Tate et al., 1993), and most likely controlled the pronounced v-shape, NS-trending Porcupine indention through the margin. This peculiar orientation, compared to adjacent basins, infers interaction of local basement and extensional faults through time which are still poorly constrained. 


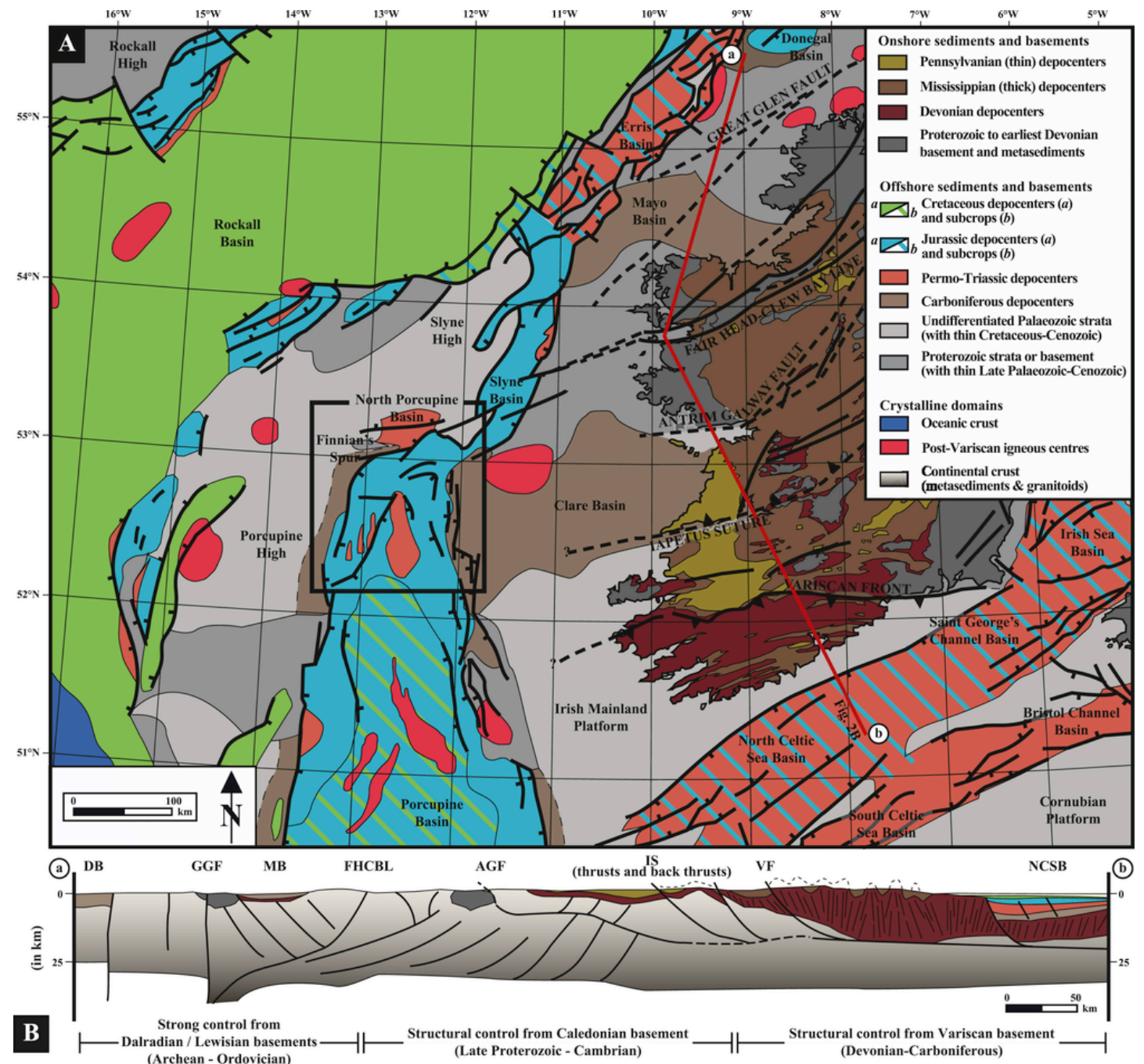

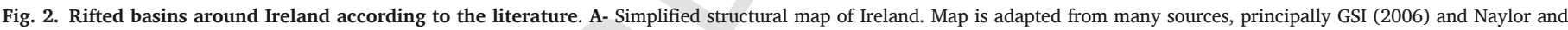

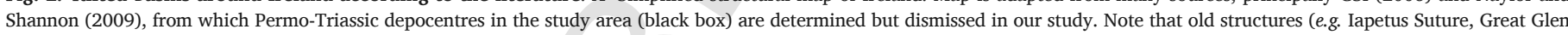

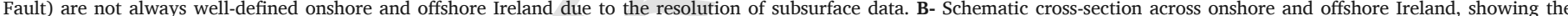

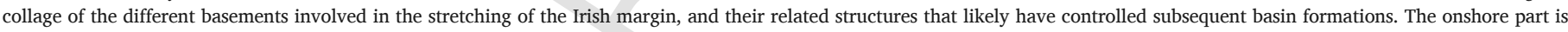

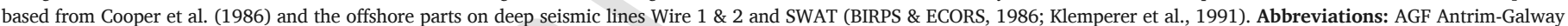
Fault, DB - Donegal Basin, FHCBL - Fair Head-Clew Bay Line, GGFZ - Great Glen Fault Zone, IS: Iapetus Suture, MB - Mayo Basin, NCSB: North Celtic Sea Basin, VF - Variscan Front.

\subsection{Crustal development of the Porcupine region}

\subsubsection{Basement configuration and Irish orogenic cycles}

Several Palaeoproterozoic to Palaeozoic basement types constitute structural highs around the Porcupine Basin (e.g. Auffret et al., 1979 \& 1987; Masson et al., 1989) and are geologically or geophysically observed underneath thick Mesozoic-Cenozoic strata or as reworked material in the basin (Robeson et al., 1988; Tate and Dobson, 1989a; Tyrrell et al., 2007). These basements reflect several orogenic cycles that aggregated the Pangaean continent and formed early discontinuities of crustal importance (e.g. Roberts et al., 1999).

The Proterozoic framework is relatively poorly constrained in the Porcupine region (Fig. 2). Palaeoproterozoic rocks are known underneath the Finnian's Spur (1.8 Ga, Daly, pers. com.) and belong to a crystalline complex extending through the Slyne-Erris and Rockall region (1.625 Ga; Miller et al., 1973; Morton and Taylor, 1991) and in northernmost Ireland (1.779-1.750 Ga, Daly et al., 1995; Daly, 1996 \& 2009). Younger Mesoproterozoic-Cambrian rocks are part of the Porcupine High $(1.31 \mathrm{Ga})$ and of the NW Atlantic fringes of Ireland (1.2-0.6
Ga). These relics formed during the Laurentian and Grenvillian orogenies that controlled the original NE-SW foundation of the margin (e.g. Great Glen Fault, Fig. 2a).

Next, the Caledonian Orogeny produced a second basement type with the Ordovician-Silurian suturing of the Iapetus Ocean along Laurentian and Grenvillian terranes (Lambert and McKerrow, 1976; Soper et al., 1999; McKerrow et al., 2000; Chew, 2009; Chew and Stillman, 2009). This formed pronounced NE-SW thrusts across the north of Ireland and Britain (e.g. Fair Head-Clew Bay Fault Zone, Iapetus Suture; Fig. 2a). In the Porcupine region, Caledonian rocks are mostly evidenced from reworked Lower Ordovician-Devonian pollens (Robeson et al., 1988).

Subsequent orogenic cycle resulted in the Variscides construction following the Devonian-Lower Carboniferous Rheic Ocean subduction (Stampfli et al., 2002; Cocks and Torsvik, 2006). Characteristic NE-SW-trending thrusts and folds in southern Ireland continue as E-W to NE-SW highs in the Celtic Sea region (Fig. 2; Cooper et al., 1984 \& 1986). Several N-S features are also known in the southern Porcupine Basin but their relation to the Variscides remains uncertain due to generally-poor seismic imaging and little age constrains, as well as superimposed 
Mesozoic extreme marginal thinning (Robinson et al., 1981; de Graciansky et al., 1985; Cook, 1987; Naylor et al., 2002). Lower Carboniferous strata are observed in the rest of the Porcupine region in lateral continuation of Carboniferous sediments across the Clare Basin (Gill, 1979; Croker, 1995) but internal deformation is poorly constrained.

\subsubsection{Late Palaeozoic-Mesozoic tectonostratigraphy and Porcupine Basin formation events}

Following these orogenic episodes, the Porcupine region encompassed repeated extension and subsidence events resulting in thick Late Palaeozoic-Mesozoic successions above crystalline basements and with uncertain links with previous orogenic basements. The tectonostratigraphic interpretation of rifted elements mostly depends on data resolution and on the attempt of reconstructing local events in the broad context of the Pangaea breakup.

The prerift basement is subdivided in two megasequences including Mississippian (Tournaisian-Lower Viséan) coarse and fine clastics, shelf carbonates and shales partially preserved in the eastern Porcupine region, followed by Pennsylvanian (Moscovian-Gzhelian) fine and coarse clastics recovered through much of the basin (e.g. Croker and Shannon, 1987; Robeson et al., 1988; Tate and Dobson, 1989a). Although part of the Carboniferous interval is coeval of the Variscides construction, compressional features remain uncertain due to the regional seismic resolution at such stratigraphic level. Similarly, Mississippian normal faulting is observed onshore along reactivated Caledonian trends (Fraser and Gawthorpe, 1990, 2003; Worthington and Walsh, 2011; Davies et al., 2012) but the fault extent in the Porcupine region is also rather vague. Both Mississippian and Pennsylvanian megasequences are separated by a regional unconformity (Late Viséan to Bashkirian) that is alternatively interpreted as a final compressional event in the closure of the Rheic Ocean or as an early effect of orogenic collapse (Praeg, 2004; Naylor and Shannon, 2011).

Overlying Permo-Triassic sediments are directly tested in the North Porcupine Basin together with possible Lower Jurassic synrift strata and are seismically-interpreted in limited fault-bounded clastic depocentres in the rest of the Porcupine region (Fig. 2a; Croker and Shannon, 1987; Naylor and Anstey, 1987; Johnston et al., 2001; Naylor et al., 2002; Štolfová and Shannon, 2009), which formed during the so-called Early Cimmerian rifting event (e.g. Sinclair et al., 1994). Following postrift intervals show Lower and Middle Jurassic shallow marine clastics and carbonates of in the North Porcupine Basin and Middle Jurassic fluvial to lacustrine clastics in the Porcupine Basin. These likely reflect the thermal subsidence of the overall margin but may also relate to the "onset warp setting" of Sinclair et al. (1994).

A second rifting phase, called Late Cimmerian rifting event, produced the most of rotational fault-blocks during the Upper Jurassic to lowermost Cretaceous (Masson and Miles, 1986; MacDonald et al., 1987; Naylor and Anstey, 1987; Croker and Klemperer, 1989; Sinclair et al., 1994; Williams et al., 1999). In these studies, the rifting onset varies between Bajocian and earliest Tithonian time, controlling a northward migration of transgressive marine facies which submerged fault-blocks by the end of the Kimmeridgian and Tithonian. The rifting termination is generally picked with the Base Cretaceous Unconformity overlain by Berriasian-Barremian shale-prone strata (postrift sediments). Yet, recent 3D seismic interpretation revealed Tithonian-Valanginian 'transitional sequences' prior the development of 'true' postrift conditions (Jones and Underhill, 2011). Further minor extension in the Aptian-Albian resulted in progradational deltaics sealed by undeformed Late Cretaceous chalk (Moore, 1992; Shannon et al., 1993). Therefore, the interval between syn- and postrift strata combines several events including uplift and thermal subsidence, the latter of which implies to reconsider the overall sequences definition.

\subsection{Aim of the present study}

The various Proterozoic-Palaeozoic orogenic episodes produced the original structural foundations of the Porcupine region, which likely shaped younger basins during Mesozoic rifting episodes (Fig. 3). Nonetheless, several major uncertainties regarding their definition and structural interactions over time still remain. For instance, the extent of Caledonian and Variscan features, largely determined from deep seismic profiles and gravity or magnetic and data, are partially known in the northernmost Porcupine Basin (Young and Bailey, 1974; Max et al., 1982; Masson et al., 1985; Klemperer, 1989; Klemperer et al., 1991) but are not accurately mapped southward due to Mesozoic and Cenozoic sedimentary thicknesses. Moreover, most studies dealt on small areas with specific hydrocarbon aspects and only a few mapped the rift-related fault zones and associated regional syn- and post-rift unconformities (Naylor and Anstey, 1987; McCann et al., 1995). In addition, these studies do not necessarily integrate the overall basin evolution in a global framework of hyper-extension (Naylor et al., 2002; PAD, 2006; Naylor and Shannon, 2011; Stoker et al., 2017), even if such scenarii have been debated in the south of the basin (e.g. Reston et al., 2001; Calvès et al., 2012; Watremez et al., 2016; Prada et al., 2017). In this context, the synrift elements recognition differs widely in the literature, implying variations of timing and significance for each event.

Our detailed mapping shows well-separated extensional episodes based on an extensive 2D and 3D seismic dataset correlated to all available wells in the study area (Fig. 4). Extension clearly started from the Carboniferous to form small and localised half-graben truncated by the Top Carboniferous Unconformity. It is followed by extension in the Rhaetian-Sinemurian, which controlled tilted blocks in the North Porcupine Basin and did not extend south of the Finnian's Spur. The third episode produced pronounced Oxfordian-Tithonian highly-rotated blocks in the Porcupine Basin and spread in the latest stage across the Finnian's Spur. Reactivation of the main bounding faults occurred during the Neocomian to form poorly-tilted and variably thick depocentres. Thus, it appears that deep crosscutting structures (e.g. Finnian's Spur) intermittently localised subsequent deformation or acted as natural barriers to the deformation. This infers fault interactions through time.

Thus, our study aims to demonstrate the extension initiation and the structural reorganisation and highlights fault reactivation processes during the rifting evolution. We also speculate on the sequences genetics in the broad context of a hyper-extended passive margin.

\section{Palaeozoic structural framework}

Pre-Mesozoic rocks, usually described as prerift basement, invariably incorporate sedimentary, metamorphic or magmatic lithologies developed during the Precambrian to the Late Palaeozoic. Therefore, they spanned several orogenic cycles, with related structures having a preponderant role on subsequent depocentres formation. Tectonic controls are, for instance, normal faulting in the Carboniferous or rifting shift across the Finnian's Spur during the Mesozoic (Fig. 4). Herein, we present well and seismic correlations of Proterozoic-Palaeozoic packages to highlight such controls across the study area.

\subsection{Lithologies}

Pre-Mesozoic lithologies are regrouped into four distinct packages made of highly metamorphosed to undeformed sedimentary rocks (Fig. 5). They are bounded by first-order stratigraphic surfaces that link to the various Precambrian and Palaeozoic orogenic cycles. Their distribution reflects a lateral continuum of depocentres, already-known across the surrounding structural highs. 


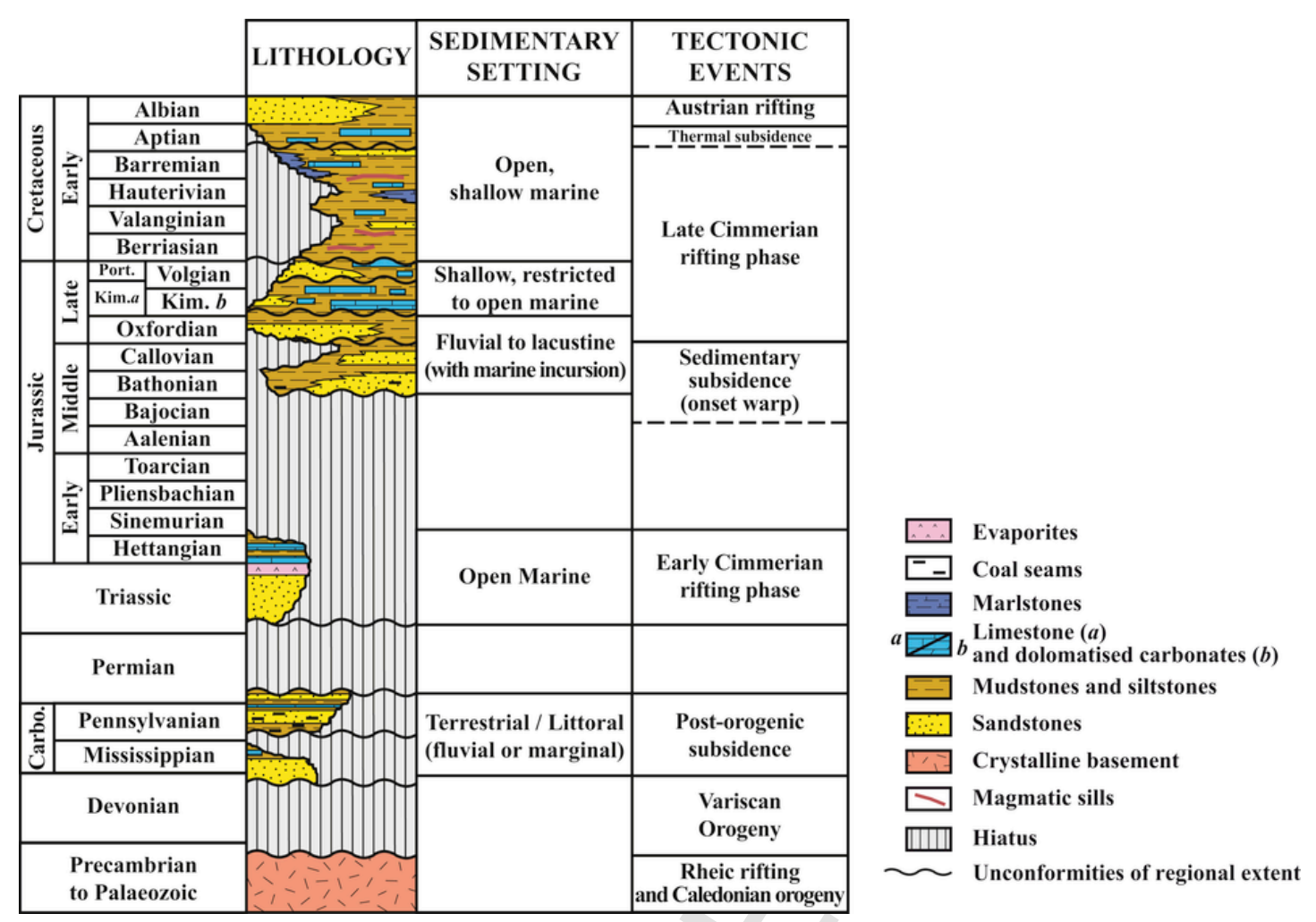

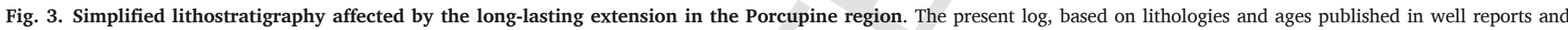

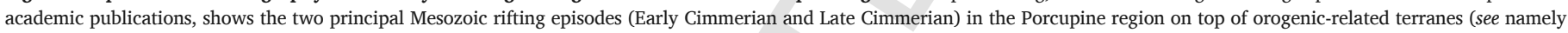
Sinclair et al. (1994), Williams et al. (1999) and Jones and Underhill (2011) for further information).

\subsubsection{Grenvillian-equivalent basement}

The oldest known basement rocks underlie structural highs west of the Porcupine Basin, such as the Finnian's Spur. Well 26/26-1 tested fractured metasediments resting on Palaeoproterozoic schists and gneisses (Fig. 5). They are probably equivalent to Dalradian rocks onshore Ireland formed during or slightly later the Grenvillian orogenic cycle.

The so-called Grenvillian Basement (GB) is topped by the Top Dalradian Unconformity (Table 1), of which the genesis is unknown due to the lack of data. Coeval unconformities may correspond to Grenvillian or Caledonian deformation phases described onshore (e.g. Hutton and Aslop, 2004; Corfu et al., 2014).

\subsubsection{Caledonian-equivalent basement}

A second basement type, composed of anchizonal to unmetamorphosed coarse clastic sediments, form a discontinuous package through the northern Porcupine region (Fig. 5). The most complete succession (Well 26/26-1) consists in a 60-to-70m-thick basal section made of conglomerates and coarse sandstones followed by finer clastics. Top units are correlatable to poorly deformed shales, siltstones and mudstones (Well 26/21-1) and quartzitic sandstones (wells 26/28-1, 26/ 28-3 and 34/5-1). Numerous carbonised spores and lithoclasts of magmatic or metamorphic origins infer a crystalline basement proximity. Basal quartzite in Well 26/28-1 was radiometrically dated as Devonian to earliest Carboniferous (Tournaisian), so that this basement type is referred herein as Caledonian Basement $(C B)$.

It is truncated by the so-called Top Devonian and Base Mississippian unconformities, sometimes observed in dipmeter data but more surely confirmed by sedimentary hiatuses spanning the Tournaisian interval (Fig. 5, Table 1). The surfaces either relate to a late compres- sional phase of the Caledonides or to the subsequent Variscides construction.

\subsubsection{Variscan-equivalent basement}

The Top Devonian and possibly the Top Dalradian unconformities are overlain by unmetamorphosed rocks, deposited during the Mississippian and forming the so-called Variscan Basement (VB). As for other basements, the distribution is unequal due to syn- and post-deposition tectonics (discontinuous depocentres, Fig. 5) but related unconformities may be predicted from well and seismic correlation (Fig. 6). The most complete succession (Well 35/15-1) shows a first section $\left(V B_{1}\right)$ composed of calcareous sandstones and micaceous siltstones passing to micritic limestones and siltstones and terminated by mudstones and fine sandstones. It is followed by a second section $\left(V B_{2}\right)$ opening on basal conglomerate overlain by limestones with brachiopods and crinoids, dolomites and volcanoclastics. The transition between both sections is genetically unclear (possible sedimentary hiatus) and may reflect localised relative uplift consistent with cyclic terrestrial to shallow-marine conditions expected from the lithology (e.g. carbonates vs shales occurrences). The Variscan Basement is further interpreted in wells 26/26-1 and 26/28-1 based on similarities in lithologies and fossil content. The biostratigraphic information suggests a latest Tournaisian-earliest Namurian age (i.e. Viséan to lower Bashkirian).

Variscan Basement is bounded by the Top Mississippian Unconformity of Namurian-Westphalian A age (i.e. Bashkirian to lowermost Moscovian, Table 1). The surface is consistent with the poor preservation of Mississippian strata in the study area and is coeval to the Variscides construction onshore Ireland.

\subsubsection{Post-Variscan Megasequence}

Carboniferous sedimentation resumed during the Pennsylvanian resulting in the regional Post Variscan Megasequence deposition (Fig. 5). A 

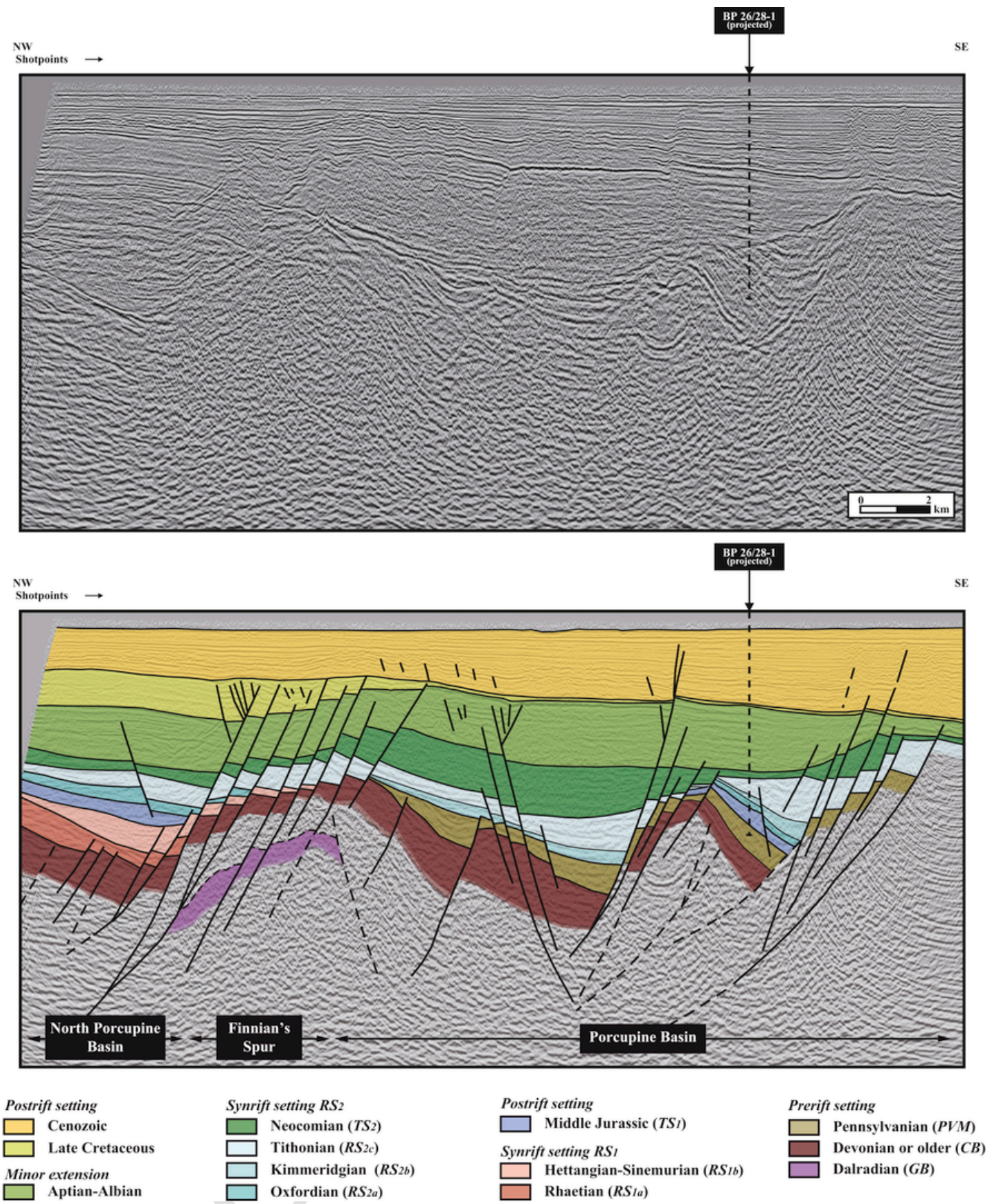

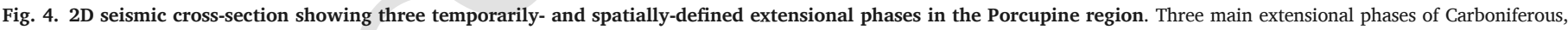

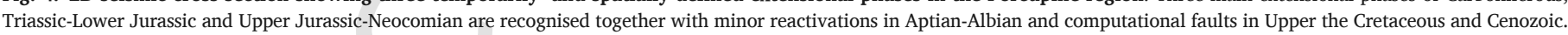

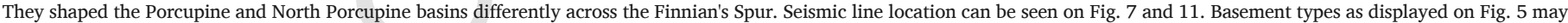

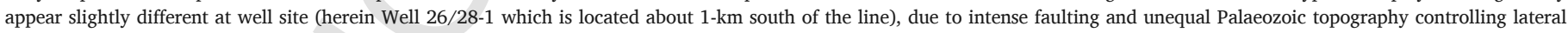
variations.

first sequence $\left(P V M_{1}\right)$ is composed of Westphalian (i.e. $\sim$ Moscovian), fining-upwards clastics alternating between conglomeratic and fine sandstones, mudstones, claystones and coal seams, which together suggest an alluvial-lacustrine environment passing progressively to littoral conditions. This is consistent with the facies distribution suggesting a progressive deepening during Westphalian $\mathrm{B} / \mathrm{C}$ and getting generalised during Westphalian D (respectively $\sim$ Duckmantian, lower and upper Bolsovian). A second section $\left(P V M_{2}\right)$, composed of mudstones and siltstones containing diverse brackish-water ostracods infers littoral persistence during the Stephanian ( upper Kasimovian-Gzhelian). A third section $\left(P V M_{3}\right.$, Well 34/15-1) consists in shales, siltstones and poorly-sorted sandstones interspaced by occasional limestones, evaporates and coal patches in which Autunian, brackish and shallow-marine ostracods are observed.

Post Variscan Megasequence is characterised by drastic thickness variations related to the remains of sequence $P V M_{1}$ and $P V M_{2}$., which may be accentuated by the Top Carboniferous Unconformity which locally merges with the Top Autunian Unconformity (Table 1). Both surfaces mark the transition Carboniferous basins with Mesozoic deposition. 


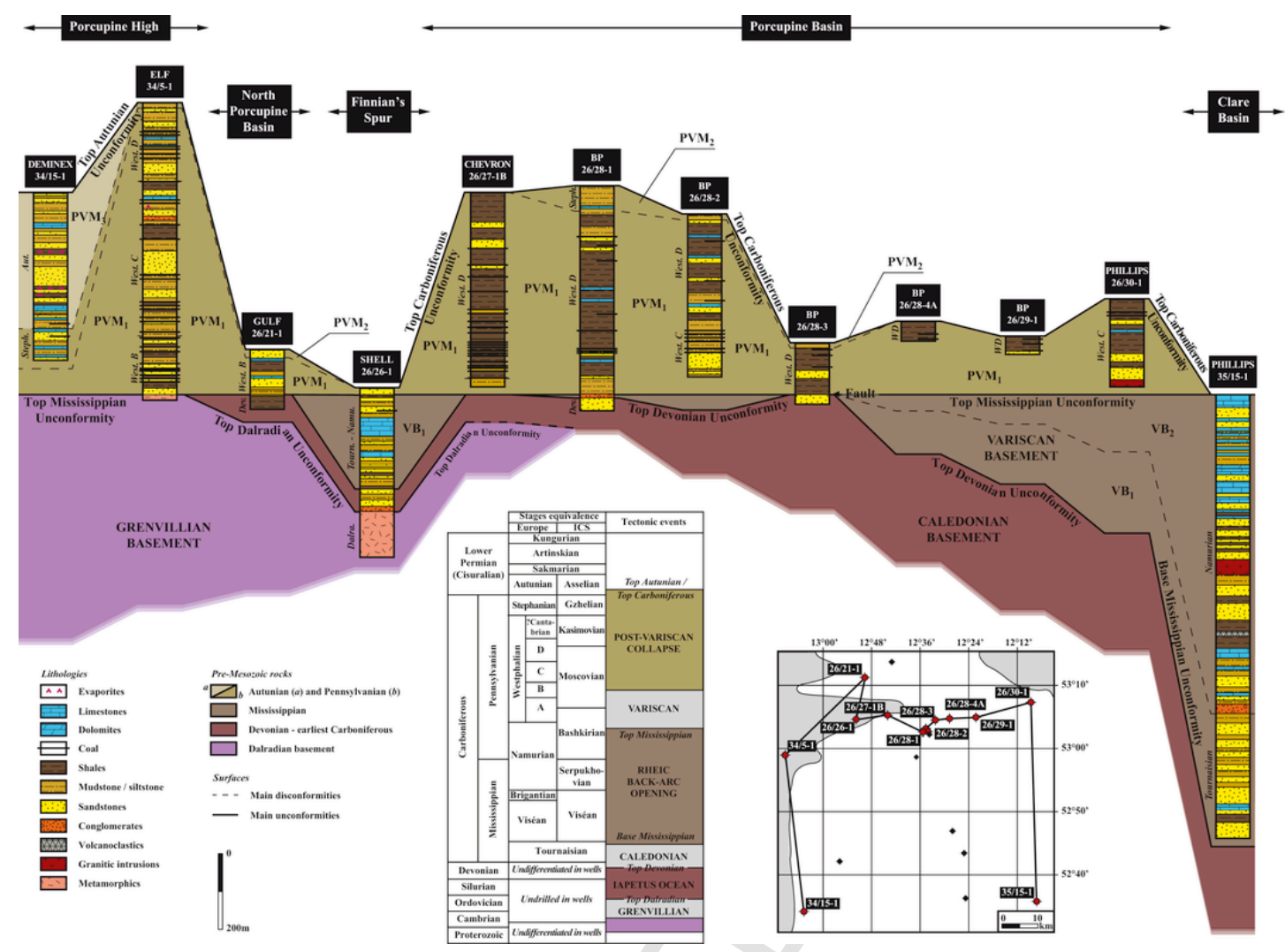

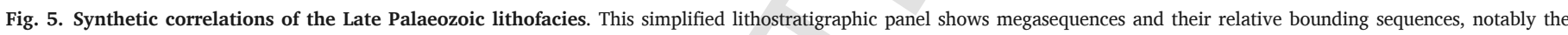

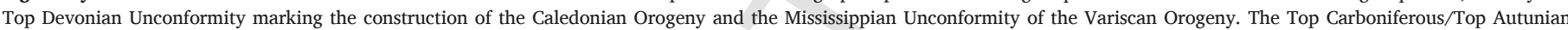

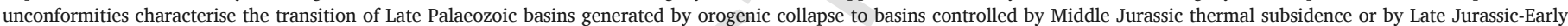

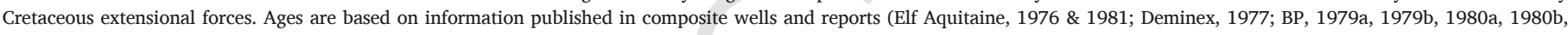

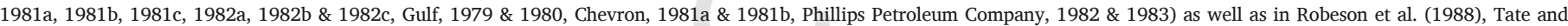
Dobson (1989a) and Croker (1995). The reader can also refer to Bulois (2016) for further lithofacies and biostratigraphic information.

\subsection{Palaeozoic tectonic phases}

Well correlation revealed four distinct basement packages, of specific ages and lithologies and separated by regional unconformities (Fig. $5)$. Their mapping through the seismic volume enables to identify different phases of regional Late Palaeozoic deformation (Fig. 6).

3D seismic data tied to Well 26/28-1 (Fig. 6A) show well-developed Caledonian Basement, resting on top of interpreted Grenvillian Basement and unconformably overlain by the Post-Variscan Megasequence. The Top Devonian and Top Mississippian unconformities merge together but their seismic distinction is difficult due to relatively thin remaining Mississippian strata (c. 10 mat well site). This supposes differential erosion of Caledonian Basement during the Variscan uplift. Internally, Devonian and Pennsylvanian sediments show tenuous but discontinuous growth-faulting, implying at least two main phases of extension. Additional syn-tectonic thickening is also observed in the Post-Variscan Megasequence. All together, this suggests succeeding extensional and compressional events liking to the Caledonides and Variscides evolution.

Correlation with Well 26/27-1B shows clearer thickening in the Post-Variscan Megasequence, controlled by normal faults rooting in the Caledonian or Grenvillian basements (Fig. 6B). The absence of Mississippian strata witnesses of the Variscan uplift incidence despite clear compression evidence.

The Variscan compression is well observed in the southeast where Mississippian strata are arranged in tectonic nappes (Fig. 6C) in lateral continuation of those observed onshore. They probably involve Devon- ian rocks, appearing in a chaotic seismic basement with some continuous reflectors that are in turn are overlain by definite Mississippian strata (Well 35/15-1) shaped in open folds controlled by décollement faults. The latter constitutes local highs (e.g. Ruadan High), partially sealed by Pennsylvanian strata of the Post-Variscan Megasequence. Overlying Pennsylvanian succession is affected by numerous normal faults, implying that the Top Mississippian Unconformity marks a transition from thrust-dominated strata (?Devonian and Mississippian) to normal-faulted depocentres (Pennsylvanian). Variscan compression indicators decrease westward, resulting in a global thickening of the Post-Variscan Megasequence along the Porcupine High (i.e. basin tilt to the west). Extension is sealed by the Top Carboniferous Unconformity in most of the central part of the basin and by the Top Autunian Unconformity in limited fault-blocks in the southwest (Well 34/15-1).

Many other rotated fault-blocks are observed through the region (Fig. 6D and E) but remain undrilled, so that it is difficult to determine an accurate age for each basin. Nonetheless, a striking element is the variation in the rotation amount that may directly result from Variscan and Caledonian basement structures reactivated during the extension. In other words, structural directions and basements rheologies have influenced the overall structural style of Late Palaeozoic extensional elements.

\subsection{Late Palaeozoic extensional tectonic patterns and fault reactivation}

Seismic analysis highlights fault-blocks principally filled in by Pennsylvanian to Autunian sediments (Post-Variscan Megasequence) on top of Caledonian or Variscan basements. Normal faults developed along E-W to ENE-WSW trends in the North Porcupine and northern Porcupine 
Table 1

Material and geometric data defining the shell natural configuration.

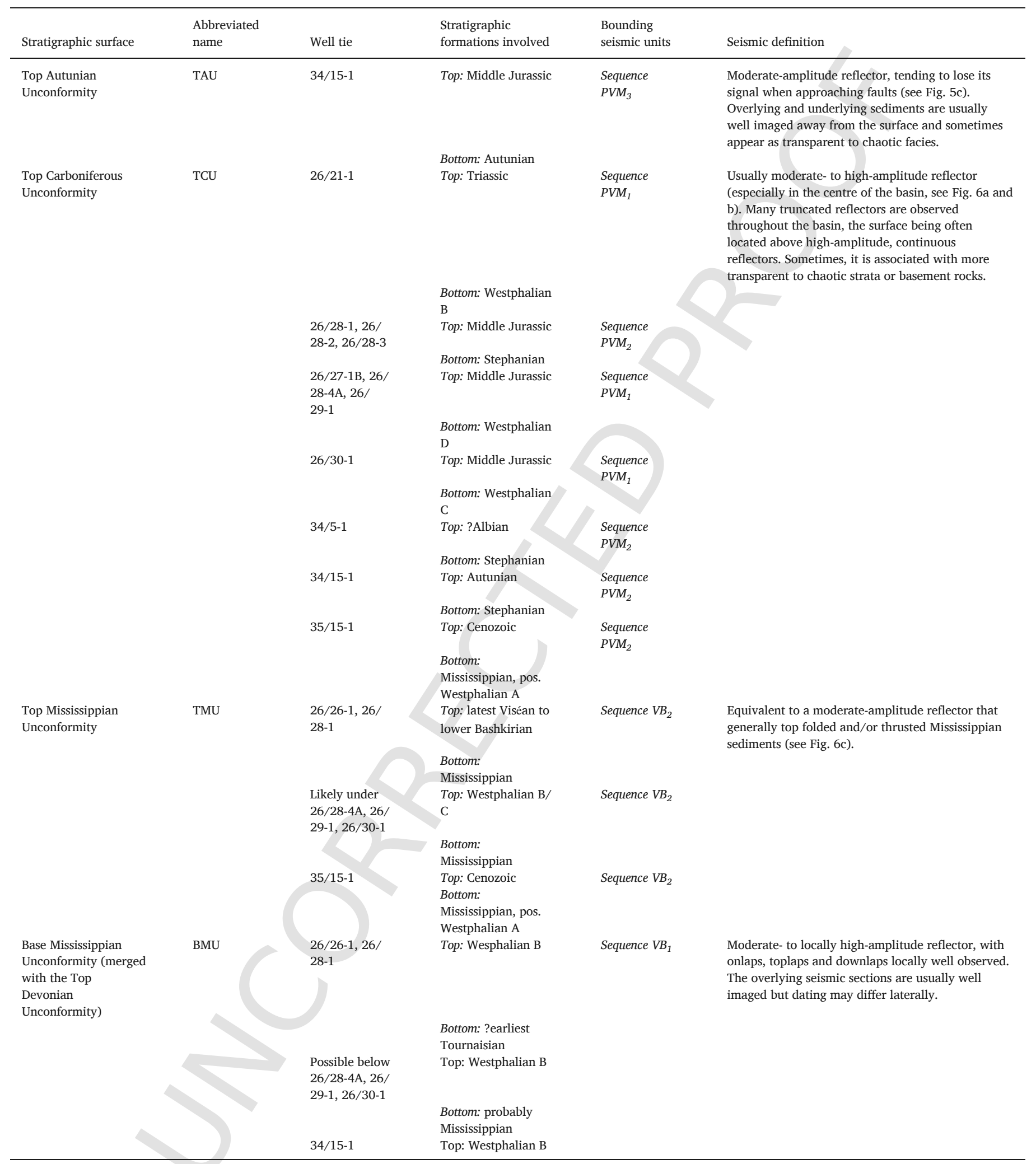


Table 1 (Continued)

\begin{tabular}{|c|c|c|c|c|c|}
\hline Stratigraphic surface & $\begin{array}{l}\text { Abbreviated } \\
\text { name }\end{array}$ & Well tie & $\begin{array}{l}\text { Stratigraphic } \\
\text { formations involved }\end{array}$ & $\begin{array}{l}\text { Bounding } \\
\text { seismic units }\end{array}$ & Seismic definition \\
\hline & & & $\begin{array}{l}\text { Bottom: } \\
\text { Palaeoproterozoic } \\
\text { (untested) }\end{array}$ & & \\
\hline $\begin{array}{l}\text { Top Devonian } \\
\text { Unconformity }\end{array}$ & TDU & $\begin{array}{l}26 / 21-1,26 / \\
26-1,26 / 28-1\end{array}$ & $\begin{array}{l}\text { Top: Viséan to } \\
\text { Serpukhovian }\end{array}$ & $\begin{array}{l}\text { Megasequence } \\
C B\end{array}$ & $\begin{array}{l}\text { Most often unclear on seismic due to seismic } \\
\text { resolution (see Fig. 6a) but the mergence with the } \\
\text { Base Mississippian Unconformity implies similarities } \\
\text { in seismic characters. }\end{array}$ \\
\hline \multirow{5}{*}{$\begin{array}{l}\text { Top Dalradian } \\
\text { Unconformity }\end{array}$} & \multirow{5}{*}{$\mathrm{TD} a \mathrm{U}$} & $26 / 28-3$ & $\begin{array}{l}\text { Bottom: Devonian } \\
\text { Top: Westphalian D } \\
\text { Bottom: Devonian }\end{array}$ & & \\
\hline & & & & $\begin{array}{l}\text { Granite } \\
\text { basement }\end{array}$ & \\
\hline & & $26 / 26-1$ & $\begin{array}{l}\text { Top: Devonian or } \\
\text { Westphalian B }\end{array}$ & $\begin{array}{l}\text { Megasequence } \\
G B\end{array}$ & \multirow[t]{3}{*}{$\begin{array}{l}\text { Most often unclear on seismic due to seismic } \\
\text { resolution. The (see Fig. } 6 \mathrm{a} \text { and b). }\end{array}$} \\
\hline & & $34 / 5-1$ & $\begin{array}{l}\text { Bottom: } \\
\text { Palaeoproterozoic }\end{array}$ & & \\
\hline & & $\begin{array}{l}\text { Likely under } \\
26 / 21-1,26 / \\
26-1,26 / \\
27-1 B, 34 / \\
15-1\end{array}$ & & & \\
\hline
\end{tabular}

Basin (north of $\sim 53^{\circ} 05^{\prime} \mathrm{N}$ ), corresponding to the local Caledonian orientation (Fig. 7). South of $53^{\circ} \mathrm{N}$, faults have a predominant N-S orientation that mark the continuation of southernmost structural highs formed during the Variscan compression. Between these two groups, faults turn to an intermediate NE-SW orientation that suggests interaction between both basements.

This implies fault clusters, whose distribution corresponds to key zones with specific deformation pattern that align along crustal basement discontinuities (Fig. 7). In the north, E-W structures are parallel to the Finnian's Spur direction, a structural fault-bounded basement feature made of Dalradian tonalitic gneisses (Grenvillian Basement) drilled in Well 26/26-1 (Figs. 4-6A; e.g. Tate and Dobson, 1989a; Tate, 1993; Naylor et al., 2002). Also, the high and other discrete narrow horsts intermittently separated the Porcupine and North Porcupine basins by localising the deformation. Adjacent Caledonian Basement appears poorly deformed (Fig. 6A and B) and its role on controlling the deformation may be only due to rheological contrasts with the adjacent Grenvillian Basement. To the west, N-S structures are parallel to the Porcupine High that is mostly composed of Precambrian and Palaeozoic rocks (Riddihough and Max, 1976; Max, 1978; Naylor et al., 1999). To the east, they run along the Ruadan High, originally described as a Mesozoic shearing and inversion feature (Tate, 1993; Naylor et al., 2002) but herein interpreted as part of a buried Variscan nappe gently reactivated afterwards separating the North Mohling and Porcupine basins (Fig. 6C).

Overall, the Palaeozoic fault distribution results in a dog-leg geometry that directly relates to the Caledonian and Variscan basements collage (Fig. 7). This strongly influenced the shape and orientation of subsequent Mesozoic extensional basins.

\section{Rhaetian and Hettangian-Sinemurian rift setting $\mathbf{R S}_{1}$}

Subsequent to Palaeozoic tectonism, the Porcupine region encompassed a period of uplift forming the Top Carboniferous and the Top Autunian unconformities, followed by an early rifting phase during the Permo-Triassic that may have affected the Porcupine region in various places (e.g. Štolfová and Shannon, 2009; Stoker et al., 2017). However, the occurrence of Permo-Triassic strata is regionally debatable as only two wells in the North Porcupine Basin (26/21-1 and 26/22-1A) directly penetrated through Triassic strata and the Top Carboniferous and Top Autunian unconformities mark clearly the contact with Jurassic strata in the Porcupine Basin (Fig. 4; Table 1). This implies to redefine this rift setting, called herein $\mathrm{RS}_{1}$ (for Rift Setting 1).

\subsection{Stratigraphy of the Rhaetian and Hettangian-Sinemurian succession}

In the North Porcupine Basin, Rift Setting $\mathrm{RS}_{1}$ controlled Megasequence $R S_{1}$ development drilled in wells 26/21-1 and 26/22-1A (Table 2). Herein, we propose to focus on Well $26 / 22-1 \mathrm{~A}$ in which sediments and related biostratigraphic content are more complete (Fig. $8 A$ ). Two main sequences, called $R S_{1 a}$ and $R S_{1 b}$, deposited on top of the Top Carboniferous Unconformity (not drilled but recognised from regional mapping around Well 26/21-1).

Sequence $R S_{1 a}$ consists of thick sandstones and intercalations of thin mudstones and siltstones with occasional anhydrites (Fig. 8A). Fossil fragments of undetermined gastropods, enchinoids, palynomorphs and fresh-to brackish-water ostracods increasing topward suggest a littoral to very shallow marine depositional environment. Palynomorphs belong to the Rhaetian-Lower Hettangian interval, assigned to the entire Sequence $R S_{1 a}$.

The boundary with overlying Lower Jurassic Sequence $R S_{1 b}$, called Top Triassic Unconformity, is picked at the level of the first carbonates occurrence in Well 26/22-1A (Fig. 8A). These usually occur in $20 \mathrm{~m}$-thick limestone beds and dolomites interbedded within mudstones and shales at the base and mudstones and calcareous sandstones upwards. Sequence $R S_{1 b}$ presents abundant palynomorphs and frequent diverse brackish to marine ostracods, and diverse marginal foraminiferas and microplanktonic specimens are getting more important compare to underlying Sequence $R S_{1 a}$. The age of the sequence is not very well-constrained although definite Sinemurian ostracods and Rhaetian to Hettangian palynofloras infer an overall Hettangian- Sinemurian age.

Paleontological information are different in nature and age from overlying strata deposited during the Middle and Upper Jurassic. This implies an unconformity on top of Sequence $R S_{1 b}$, called Top Lower Jurassic Unconformity, which merges with younger Mesozoic unconformities on top of the Finnian's Spur (Fig. 4).

Megasequence $R S_{1 a}$ is mapped through the seismic volume based on the recognition of the three above-mentioned bounding unconformities. It extends northward to fill in the entire North Porcupine Basin and is limited by the Finnian's Spur to the south (Table 2, Figs. 4-8B). Thus, Permo-Triassic pockets proposed in the Porcupine Basin (e.g. 

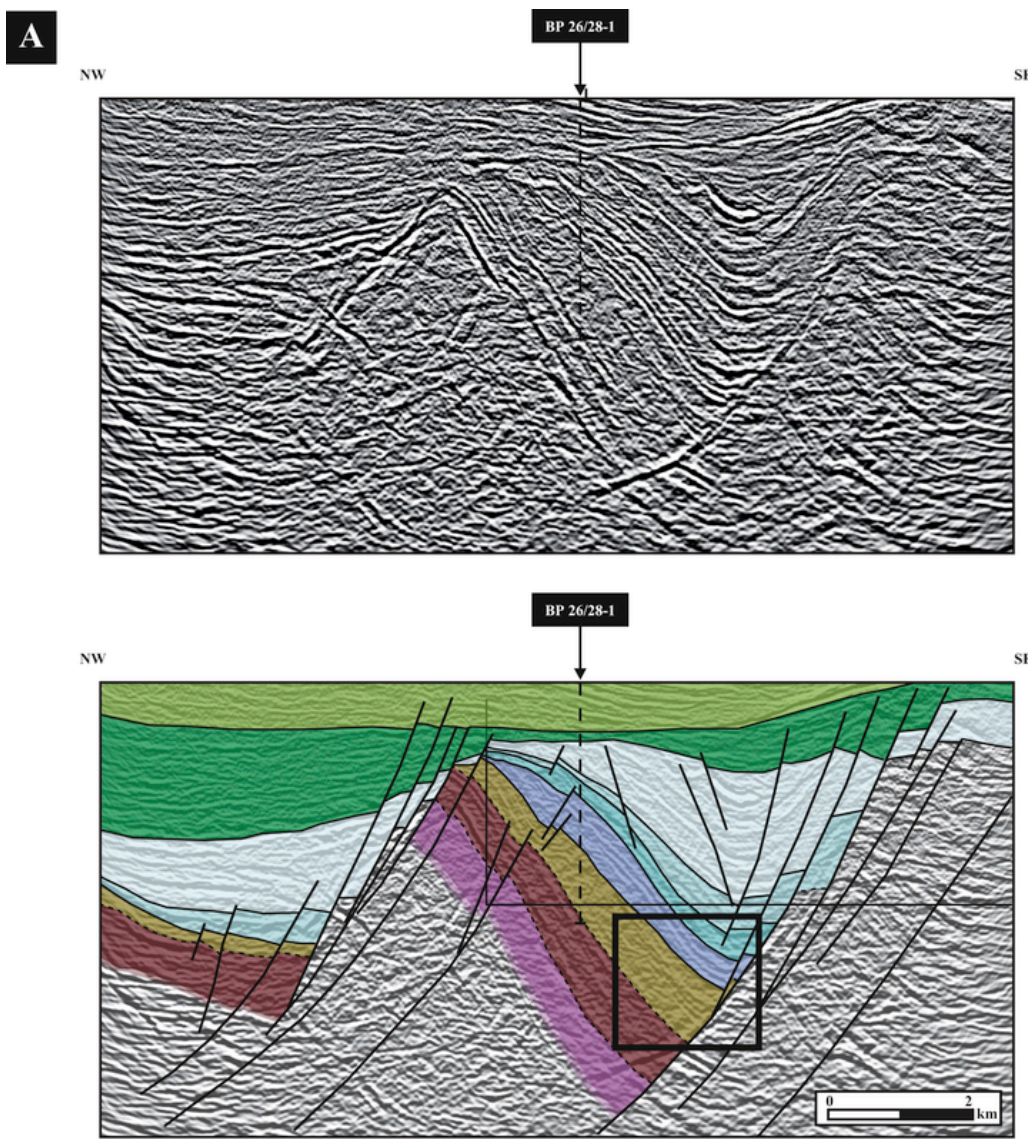

Interpreted lithologies

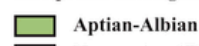

$\square$ Neocomian $\left(T S_{2}\right)$
$\square$ Portlandian/Volgian $\left(R S_{2 c}\right)$
$\square$ Kimmeridgian $\left(R S_{2 b}\right)$

Oxfordian $\left(R S_{2 a}\right)$

Middle Jurassic $(T S t)$

Pennsylvanian $(P V M)$

Devonian - earliest Carboniferous ( $C B$ )

\pm Mississippian ( $V B$, unmapped)

Dalradian $(G B)$
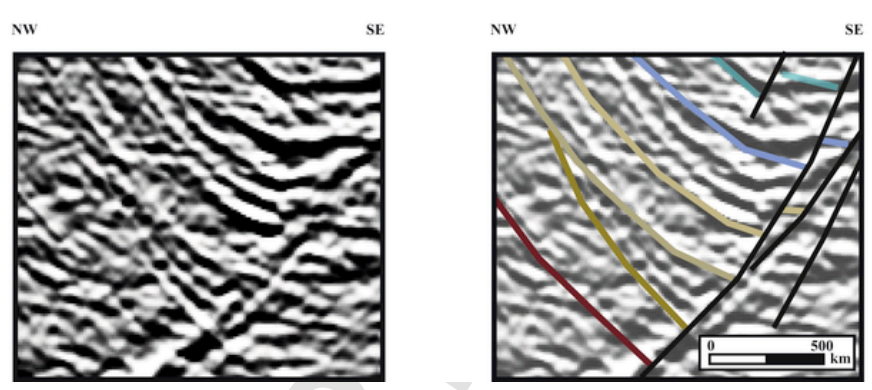

Interpreted surfaces

_ Base Kimmeridgian Disconformity

_ Base Oxfordian Disconformity

_- Top Carboniferous Unconformity

_- Base Stephanian Disconformity

_ Intra Westphalian Disconformity

Top Mississippian / Top Devonian unconformities

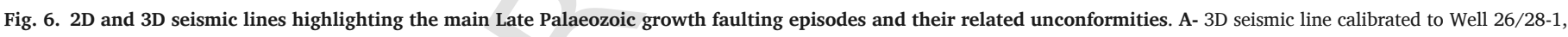

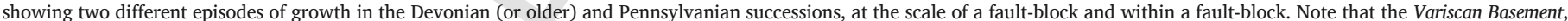

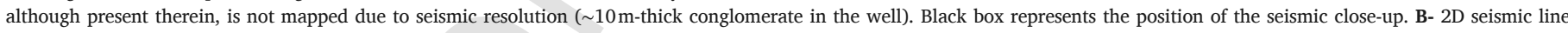

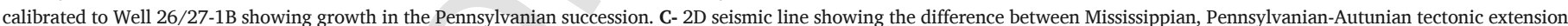

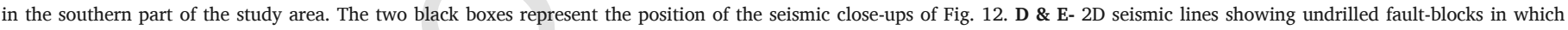
Palaeozoic rocks are differentiated according to the seismic characters and the internal deformation patterns. Seismic lines and wells location can be seen on Fig. 7.

Naylor et al., 2002) are most likely Westphalian-to-Stephanian in age according to our seismic interpretations. In the North Porcupine Basin, the Top Carboniferous Unconformity corresponds to truncated Carboniferous reflectors onlaped by Sequence $R S_{1 a}$. The Top Triassic Unconformity is characterised by medium-to strong-amplitude reflectors correlative to the top of massive sands and the first occurrence of carbonates in Sequence $R S_{1 b}$. The Top Lower Jurassic Unconformity is determined from localised Middle Jurassic truncations and onlaps. The three surfaces merge the one another north of the North Porcupine Basin (i.e. southward basin tilt).

\subsection{Rhaetian and Hettangian-Sinemurian normal faults}

Several normal faults have controlled the deposition of both sequences $R S_{1 a}$ and $R S_{1 b}$ (Fig. 8B). Sequence $R S_{1 a}$ affects that north-tilted normal faults is most generally limited into small hemi-graben. Faulting did not propagate up to the Top Triassic Unconformity, implying a partially tectonically-driven subsidence. This is consistent with the general base-level rise observed in Well 26/22-1A. Largest faults have been later reactivated during the Hettangian-Sinemurian to control Sequence $R S_{1 b}$ deposition. This lead us to consider two distinct extensional episodes during the Triassic-Lower Jurassic period, whose the transition is marked by the Top Triassic Unconformity.

Fig. 9 displays the subcrop map of fault trends that controlled Sequence $R S_{1 a}$ (Rhaetian). They are oriented along E-W and ENE-WSW directions that are parallel to the Finnian's Spur and therefore correspond to reactivated Late Palaeozoic faults (Fig. 7). In the absence of Triassic-Lower Jurassic strata south of the Finnian's Spur, it is likely that these faults mark the southernmost boundary of the Rift Setting $\mathrm{RS}_{1}$. Also, we propose that most of the northern part of the Porcupine 

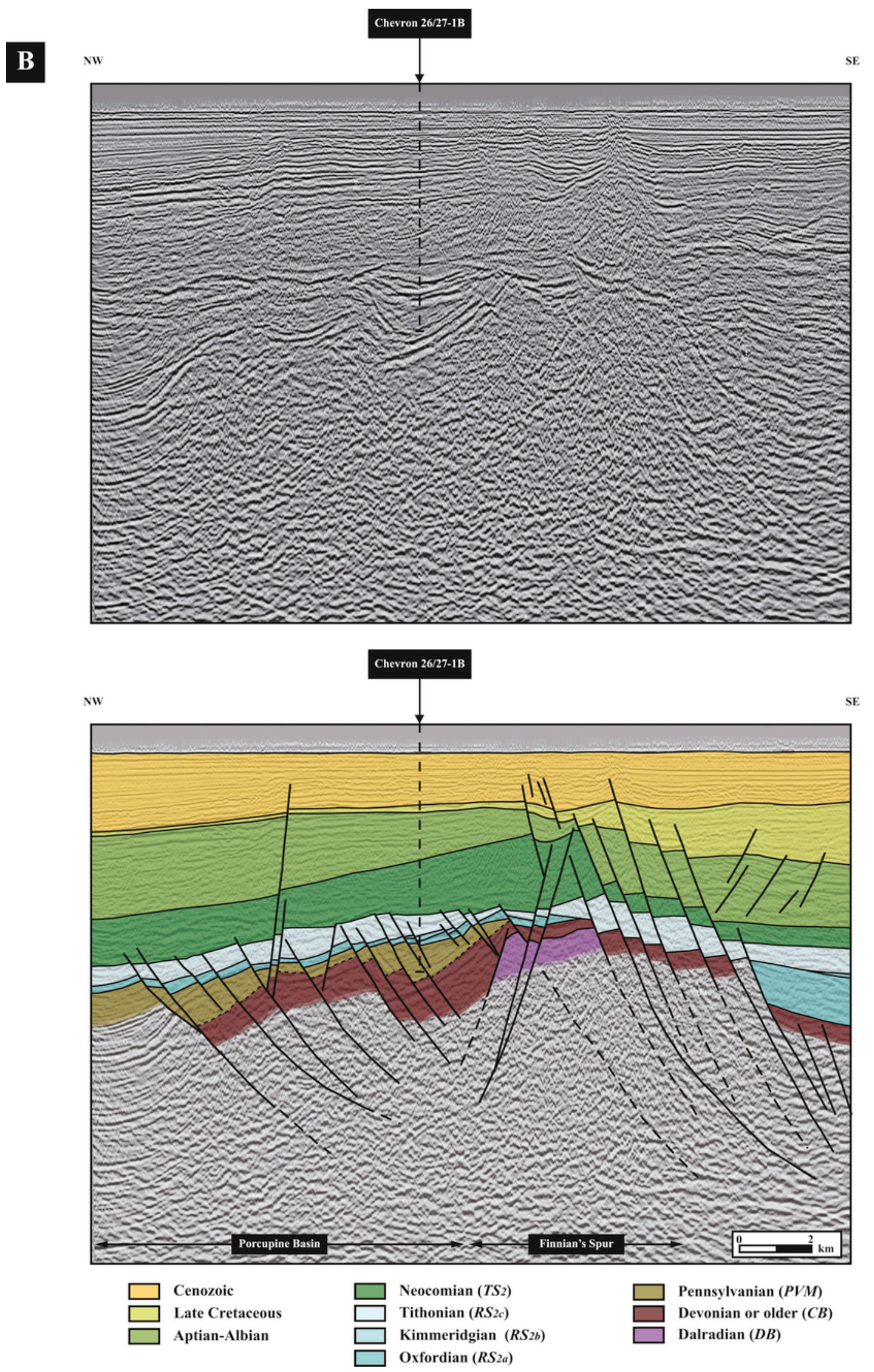

Fig. 6. (Continued) 


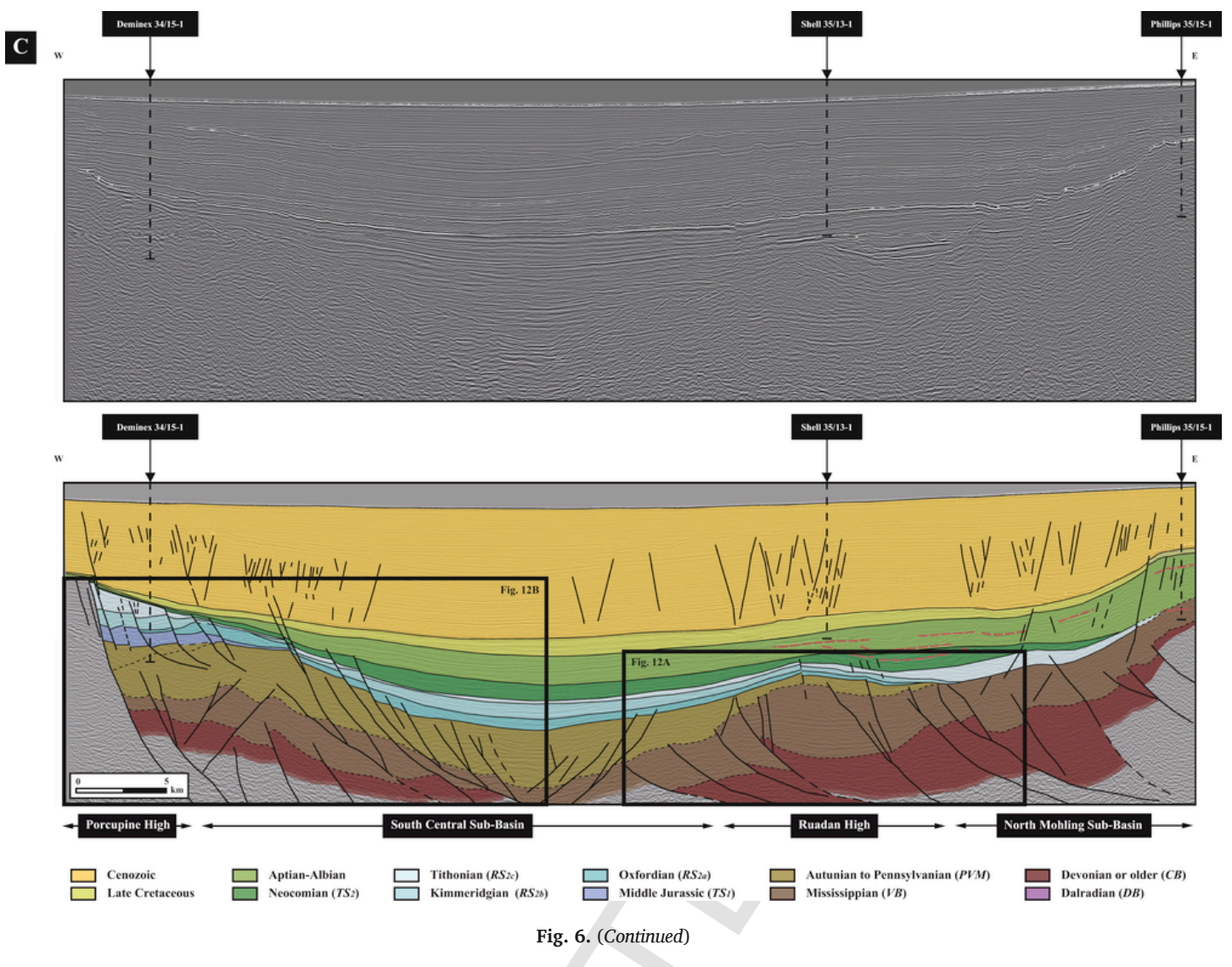

uplifted between the latest Carboniferous to Middle Jurassic interval, and that the North Porcupine Basin evolved independently of the Porcupine Basin at the time.

\section{Upper Jurassic to Lower Cretaceous rift setting $\mathrm{RS}_{2}$}

A second, generally more intense rift episode affected most of the Porcupine region and is here called $\mathrm{RS}_{2}$ (for Rift Setting 2) for similar reasons than previous Rift Setting $\mathrm{RS}_{1}$. Although its definition widely differs in the literature due to internal facies recognition, the synrift unconformity is generally assumed running at the base of the Upper Jurassic and the postrift unconformity at the Base Cretaceous Unconformity (Late Cimmerian rifting phase on Fig. 3). Herein, we redefine this overall synrift setting using all available well and seismic data and reconsider the such surface definitions at basin scale.

\subsection{Stratigraphy of the Mid-to Upper Jurassic and Lower Cretaceous intervals}

To define the synrift interval, we take the example of Well 26/ 28-A1 that shows a complete Middle Jurassic to Lower Cretaceous succession deposited on top of Carboniferous strata (Fig. 10A). The first sediments, contained in Megasequence $T S_{1}$ (for Transitional Setting 1, $369 \mathrm{~m}$-thick), are composed of shally, silty and muddy material interbedded with repeated thick (1-to-10 m) clastic levels (coarse or conglomeratic sands) and occasional coal (seams or patches), deposited within a fluvial-lacustrine environment. Numerous plant articles, bisaacate pollens and increasing upward fresh-to brackish-water ostracods, belong to the Bathonian interval. Megasequence $T S_{1}$ is toped by the Base Oxfordian Unconformity witnessed by a regional absence of Callovian strata (Table 3).
Subsequent Megasequence $R S_{2}$ (for Rift Setting 2, $242 \mathrm{~m}$-thick) is subdivided into three Upper Jurassic sequences (Fig. 10A). Sequence $R S_{2 a}$ (Oxfordian) contains sandstones, mudstones and siltstones and the first occurrence of carbonates (patches or thin beds). Terrestrial and brackish species, including palynofloras, plant articles, dynoflagellates and ostracods, are observed with brackish to shallow-marine foraminiferas, brachiopods, echinoderms and gastropods. Strata are therefore interpreted to have deposited in an estuarine to coastal plain context. Following Sequence $R S_{2 b}$ (Kimmeridgian) is picked from the absence of sands and the first appearance of thick limestone beds $(>5 \mathrm{~m})$ interbedded within siltstones and mudstones. A very diverse assemblage of dynophycaea, ostracods, foraminiferas, marine bivalves, brachiopods or echinorderms is observed throughout. The sequence therefore deposited in a marginal marine environment. Overlying Sequence $R S_{2 c}$ (uppermost Kimmeridgian and Tithonian) is mudstone-dominated and incorporates almost exclusively marine species (varied dynoflagellates, foraminiferas and fragmented of echinoderms, gastropods and bivalves). Overall, Megasequence $\mathrm{RS}_{2}$ shows a progressive base-level rise that most likely terminated with the construction of the Base Cretaceous Unconformity.

Following Megasequence $\mathrm{TS}_{2}$ (for Transitional Setting 2, ca. $40 \mathrm{~m}$-thick) consists in mudstones and limited sandy and carbonate levels (Fig. 10A), sealed by disconformable massive Aptian-Albian sandstones and mudstones. The lowermost part of the sequence is poorly dated and the contact pattern with overlying Aptian-Albian strata, although disconformable in the well, may represent a clear unconformity in other wells (see Bulois (2016) for further discussion). Megasequence $\mathrm{TS}_{2}$ contains almost exclusively marine species including foraminiferas, dynophyceae and more minor ostracods that belong to the Berriasian-Barremian interval. It is topped by a regional unconformity, called Top Neocomian Unconformity that produced a condensed succession at well site (Fig. 10B). The thickness and facies nature vary throughout 
D

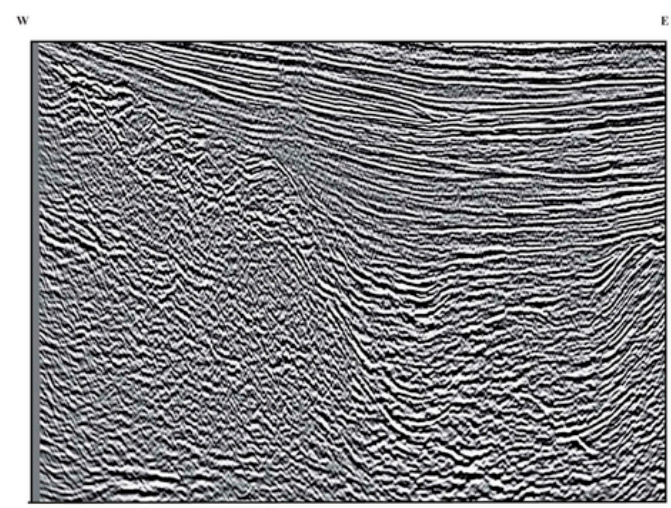

w
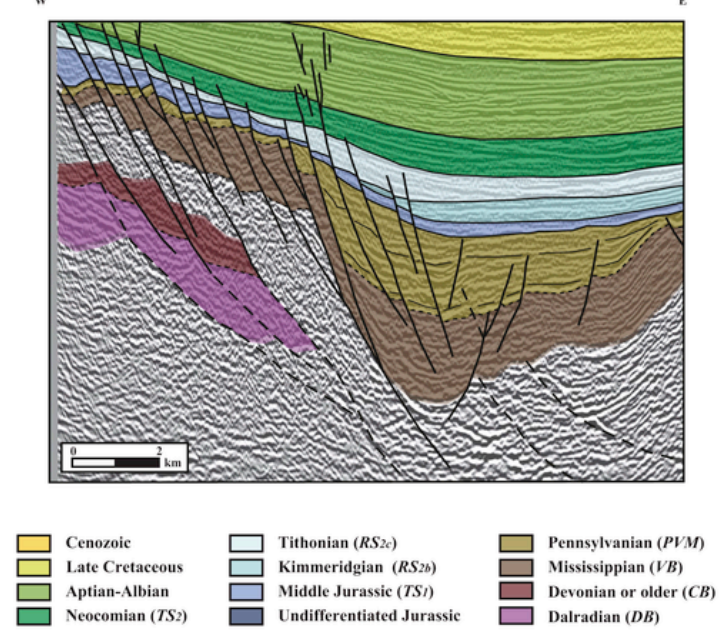

E
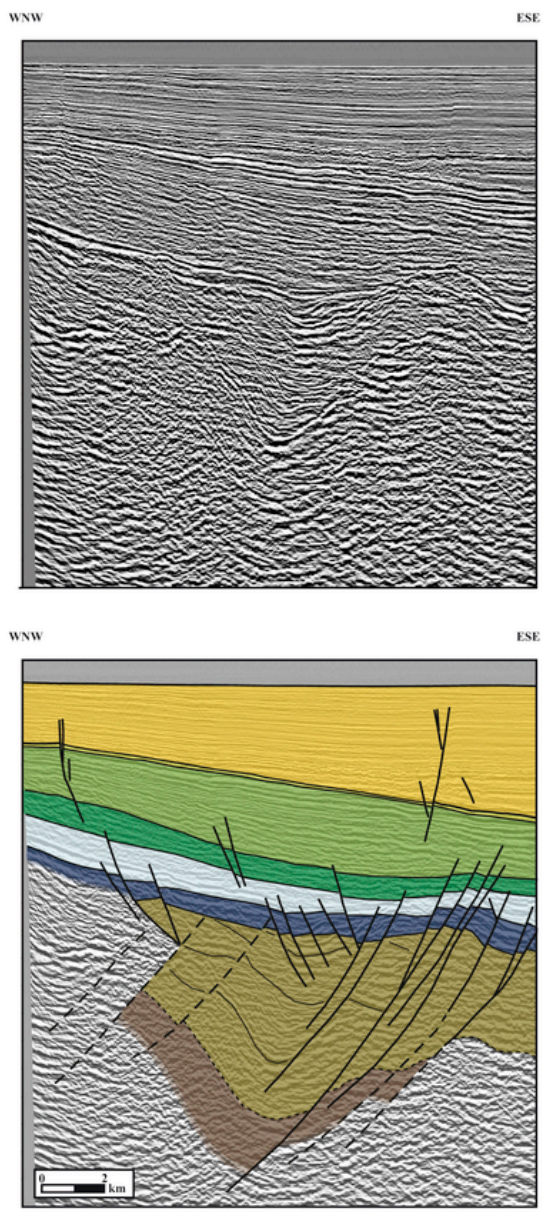

Fig. 6. (Continued)

the study area, as a result of the installation of the Rift Setting $\mathrm{RS}_{2}$ (see differences between Figs. 8A-10A).

\subsection{Seismic expression of the Middle Jurassic-Lower Cretaceous interval}

The three previously-described megasequences are correlated to the entire seismic volume (Fig. 10B), together with unconformities of regional extent (Table 3). All of these have specific varying depositional controls.

Above the Top Carboniferous Unconformity, Megasequence $T_{1}$ is characterised by parallel to subparallel, subcontinuous reflectors of medium-to-strong amplitude (Fig. 10B). This geometry implies the absence of faulting but, instead, a strong subsidence as witnessed by the generalised fluvial-alluvial to lacustrine transition. Subsidence relates to thermal cooling following Rift Setting $\mathrm{RS}_{1}$ in the North Porcupine Basin and clearly predates the installation of the Upper Jurassic-Neocomian Rift Setting $\left(\mathrm{RS}_{2}\right)$.

Megasequence $R S_{2}$, bounded by the Base Oxfordian and the Base Cretaceous unconformities, is characterised by intense growth-faulting. Oxfordian Sequence $R S_{2 a}$ displays subparallel to slightly oblique, subcontinuous reflectors, witnessing of subtle thickening (Fig. 10B). Subsequent Kimmeridgian Sequence $R S_{2 b}$ shows continuous reflectors and much more pronounced thickening toward the bounding faults. Finally, Tithonian Sequence $R S_{2 c}$ shows medium-to strong-amplitude, continuous reflectors that expand beyond the limits of sequences $R S_{2 a}$ and $R S_{2 b}$. This confirms the overall Upper Jurassic marine transgression as described in the above. Nonetheless, deposition and deformation are not homogeneous as observed on regional seismic lines (Figs. 4 and 6).
This implies timing or magnitude variations of regional extent that directly link to fault expression.

Upper Jurassic strata are followed by Megasequence $T S_{2}$, sandwiched by the Base Cretaceous and the Top Neocomian unconformities (Fig. 10B). Depocentres are only limited by the main Upper Jurassic faults that progressively die out during the Neocomian. Strata are generally sub-horizontal, implying a rather reduced tectonic control compare to underlying Megasequence $R S_{2}$. Thus, Megasequence TS2 suggests a progressive and uniform sag.

\subsection{Upper Jurassic-Lower Cretaceous tectonism and relations with earlier structural trends}

The analysis of the present 2D and 3D seismic dataset enabled the recognition of several fault orientations to Late Palaeozoic trends (Figs. 7 and 11). EW and ENE-WSW faults are dominant in the northwestern part of the Porcupine Basin and in the North Porcupine Basin, where they run parallel to the Finnian's Spur, before turning to NE-SW trend in the northeastern part of the Porcupine Basin. N-S faults appear locally in the north but prevail south of latitude $53^{\circ} \mathrm{N}$, in continuation of the Ruadan High. They rotate to a NNE-SSW orientation in the southeastern part of the Porcupine Basin. Such a fault cluster marks the strong v-shape of the overall Porcupine Basin.

Fig. 12 shows the structural relationships existing between Rift Setting $\mathrm{RS}_{2}$ and underlying Palaeozoic structures. In the southern part of the basin, high-resolution seismic imaging show Carboniferous folds and thrusts, that relate to characteristic thin-skinned Variscan deformation (Fig. 12A). They form buried structural highs, such as the Ruadan 


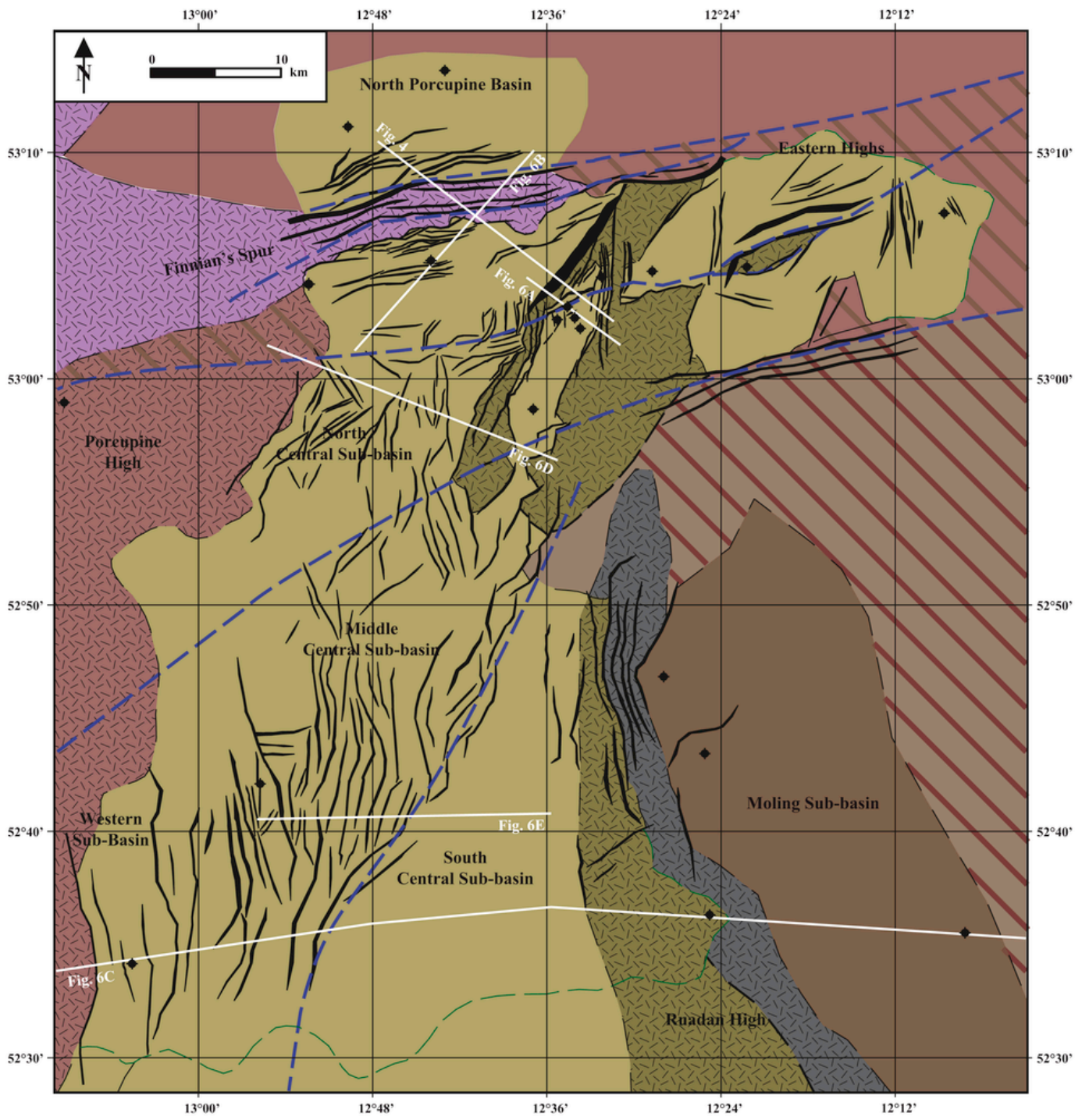

Main depocentres

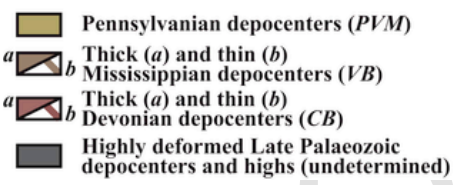

Structures

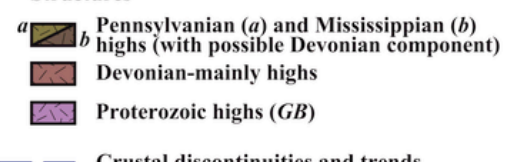

${ }^{a} \square$ Pennsylvanian (a) and Mississippian (b)

Devonian-mainly highs

- Crustal discontinuities and trends
Others

- Limite of interpretation

$+\quad$ Wells

Fig. 7. Map showing the fault network affecting Megasequence PVM (Pennsylvanian) in the Porcupine region.

High, which clearly controlled the thickness of subsequent Upper Jurassic-Lower Cretaceous strata. To the west (Fig. 12B), extension produced normal faults flattening along Pennsylvanian sedimentary levels interpreted as lithological changes (e.g. higher rate of shale) or variation of structural styles (e.g. change in the fault dips and lesser compressional faults). This produced sliding packages that link onto faults basinward. In the northern part of the Porcupine Basin (Fig. 12C), asymmetrical to slightly overturned folds, locally associated with thrusts, controlled subsequent Pennsylvanian and Upper Jurassic-Lower Cretaceous normal faults that root on their forelimbs (flat part) and progressively upright in the upper part of the sedimentary succession. These structural relations imply a strong control of the Variscan structures onto the $\mathrm{RS}_{2}$-related extension, which decreases northward due to the Caledonian Basement predominance.

\section{Discussion}

Our seismic analysis has shown various extensional megasequences that each reflects specific periods encompassed by the Porcupine region. Herein, we discuss them in terms of margin dynamics in order to constrain the structural response to the faulting propagation at a crustal scale and to conceptualise how inheritance and fault reactivation processes shaped the region in separated extensional frameworks.

\subsection{Overlapping extensional megacycles}

In the study area, several structural trends have been intermittently active since the Late Palaeozoic and relate to the internal basement geometries issued from the Variscan, Caledonian and, to a minor ex- 
Table 2

Well and seismic characteristics of unconformities associated with the rift system RS1 in the North Porcupine Basin.

\begin{tabular}{|c|c|c|c|c|c|}
\hline $\begin{array}{l}\text { Stratigraphic } \\
\text { surface }\end{array}$ & $\begin{array}{l}\text { Abbreviated } \\
\text { name }\end{array}$ & Well tie & $\begin{array}{l}\text { Stratigraphic } \\
\text { formations involved }\end{array}$ & $\begin{array}{l}\text { Bounding } \\
\text { seismic } \\
\text { sequence }\end{array}$ & Seismic definition \\
\hline $\begin{array}{l}\text { Top Lower Jurassic } \\
\text { Unconformity }\end{array}$ & TLJU & $\begin{array}{l}26 / 21-1 \\
26 / 22-1 A\end{array}$ & $\begin{array}{l}\text { Top: Bathonian, } \\
\text { locally Neocomian } \\
\text { Bottom: Hettangian- } \\
\text { Sinemurian (Zone } \\
\mathrm{RS}_{\mathrm{Ib}} \text { ) }\end{array}$ & Sequence $R S_{1 a}$ & $\begin{array}{l}\text { Medium- to strong-amplitude reflector, with many onlap } \\
\text { or downlap patterns in overlying Zone } \mathrm{TS}_{1} \text { and/or clear } \\
\text { truncational reflectors and erosional features in } \\
\text { underlying Zone } \mathrm{RS}_{1 \mathrm{~b}} \text {. }\end{array}$ \\
\hline $\begin{array}{l}\text { Top Triassic } \\
\text { Unconformity }\end{array}$ & TTU & $\begin{array}{l}26 / 21-1 \\
26 / 22-1 A\end{array}$ & $\begin{array}{l}\text { Top: Hettangian- } \\
\text { Sinemurian (Zone } \\
\mathrm{RS}_{\mathrm{Ib}} \text { ) } \\
\text { Bottom: Rhaetian } \\
\text { (Zone } \mathrm{RS}_{\mathrm{Ia}} \text { ) }\end{array}$ & Sequence $R S_{1 b}$ & $\begin{array}{l}\text { Medium- to strong-amplitude reflector, without clear } \\
\text { onlap, downlap or clear truncational reflectors or } \\
\text { erosional features. }\end{array}$ \\
\hline $\begin{array}{l}\text { Top Carboniferous } \\
\text { Unconformity }\end{array}$ & TCU & $26 / 21-1$ & $\begin{array}{l}\text { Top: Triassic } \\
\text { Bottom: Westphalian } \\
\text { B }\end{array}$ & $\begin{array}{l}\text { Sequence } \\
\mathrm{PVM}_{2}\end{array}$ & $\begin{array}{l}\text { Medium reflectors, usually continuous, and that locally } \\
\text { display internal deformation due to prior Palaeozoic } \\
\text { tectonism. }\end{array}$ \\
\hline
\end{tabular}

tent, Grenvillian compression phases. In the present study, we argue that the deep crustal structures had varying controls on the structural development over a long period of time, resulting in three overlapping extensional systems. These events can be considered as separated extensional megacycles (sensu Bulois et al., 2017), controlled by either volume or plate dynamics forces (i.e. orogenic collapse or true rifting). They therefore express differently the overall faulting propagation though the region.

Upper Palaeozoic extension results in slightly-rotated extensional basins formed along E-W and NE-SW Caledonian trends in the north of the basin and N-S Variscan thrusts and folds directions in the south (Fig. 13A). In the Porcupine Basin, Upper Palaeozoic depocentres seem to propagate from east to west and south to north, inferring a progressive collapse of the Variscan Orogen and a poorer control of Caledonian structures at the time of deposition. This type of extension is confirmed by the continental to very-shallow-marine conditions identified throughout Megasequence $\mathrm{PVM}_{2}$ (our study) and extensional stages identified onshore (Praeg, 2004). Subsequent Rift Setting $\mathrm{RS}_{1}$ corresponds to an Upper Triassic-Lower Jurassic rifting phase, restrained to the North Porcupine Basin as it abutted the Finnian's Spur (Fig. 13B). As a result, reactivation of E-W/ENE-WSW Caledonian trends controlled shallow marine depocentres (Megasequence $R S_{1}$ ) interpreted as the southern extent of a southwards-propagating rift setting linked to the early Permo-Triassic Arctic rift setting (Ziegler, 1988; Roberts et al., 1999). Final Rift Setting $\mathrm{RS}_{2}$ took place mostly in the Porcupine Basin during the Upper Jurassic and continued during the Neocomian (Fig. 13C). It resulted in shallow-to-deep-marine depocentres through both basins, with deposition due to the tectonic development of the northward-propagating North Atlantic Ocean (Ziegler, 1988; Roberts et al., 1999; Doré et al., 1999) and, to a certain extent, of the Central Atlantic Ocean (Stampfli and Borel, 2002; Nirrengarten et al., 2017). Further extensional episodes in the Aptian-Albian and the Cenozoic are not taken into account in our study as they have had very minor effects on the overall geometry of the Porcupine Basin (Figs. 6, 8 and 10). They are likely to represent deviatoric stresses arising from other plate settings (e.g. opening of the Bay of Biscay or of the North Atlantic Ocean sensu stricto).

In our overall evolutionary concept (Fig. 13), extension progressively migrated from the initial deformation core by reactivating pre-existing orogenic structures and stopped when abutting transversal lineaments. Thus, Caledonian faults initiated and stopped both Triassic-
Lower Jurassic and Upper Jurassic-Neocomian extensional phases, while the Variscan Fold Belt, concordant with the Ruadan High, localised Upper Jurassic extension alongside to give the general N-S direction but also stopped the extension further northeast when bending to the more characteristic E-W orientation. Previous palaeogeographic reconstructions showed similar dog-leg shape for the regional Variscan trends (e.g. Ziegler, 1988; Ballèvre et al., 2013). Nonetheless, we consider herein that such shape is produced by the collage and internal structures of both Variscan and Caledonian terranes.

Our dataset also suggests that such structural interactions controlled, at least partially, the characteristic v-shaped geometry of the overall Porcupine Basin. This implies a propagator mechanism developing accordingly to two different thickened continental crusts (Caledonian and Variscan) of specific structural patterns. This is confirmed by higher finite extension to the south with lithospheric stretching factors $(\beta)$ grading from 1.1 to 1.7 to the north to more than 6 to the south (Tate et al., 1993). In parallel, extreme crustal thinning and serpentinised mantle is observed on deep refraction profiles southward (Readman et al., 2005; O'Reilly et al., 2006; Watremez et al., 2016; Prada et al., 2017) and new seismic refraction models suggest the presence of oceanic crust in the southernmost part of the Porcupine Basin (Chen et al., 2017, submitted). This likely relates to the uppermost Jurassic and Neocomian continental rifting in the Porcupine Basin and coeval uplift in the North Porcupine Basin, resulting in thick strata in the south than thin northward. In that sense, the differential response of the Caledonian and Variscan structures provided, at least partially, the shape of the overall basin within the Irish Atlantic Margin evolution framework.

This global mechanism is similar to the ones considered for other propagator settings such as the Coral, South China or southwestern Barents seas where heterogeneities at crustal and lithospheric scales partly controlled the development of rift propagators in addition of sequent extensional systems (Gernigon et al., 2014; Savva et al., 2014; Bulois et al., 2017). Therefore, their evolution combines successive extensional megacycles developing according to the reactivation of early crustal discontinuities and in respect of the overall boundary conditions variations. In the case of the Porcupine Basin, the Aptian-Albian Bay of Biscay opening probably stopped extension in the Porcupine Basin and forced relocation of the deformation in the Rockall and Hatton region (e.g. Srivastava and Verhoef, 1992; Doré et al., 1999; Roberts et al., 1999; Tugend et al., 2015). 
$\mathbf{A}$
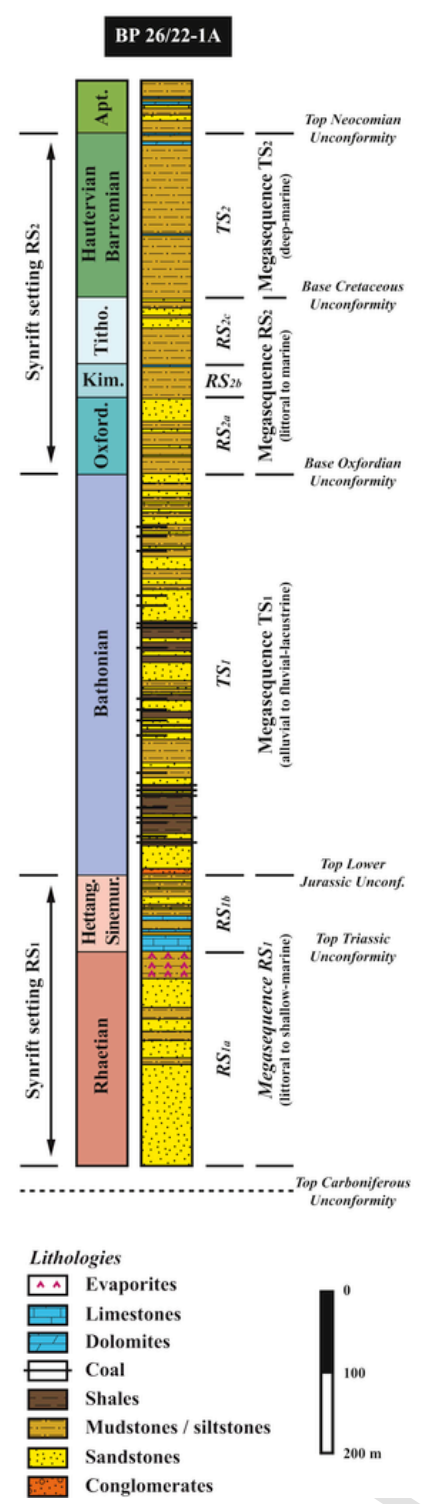
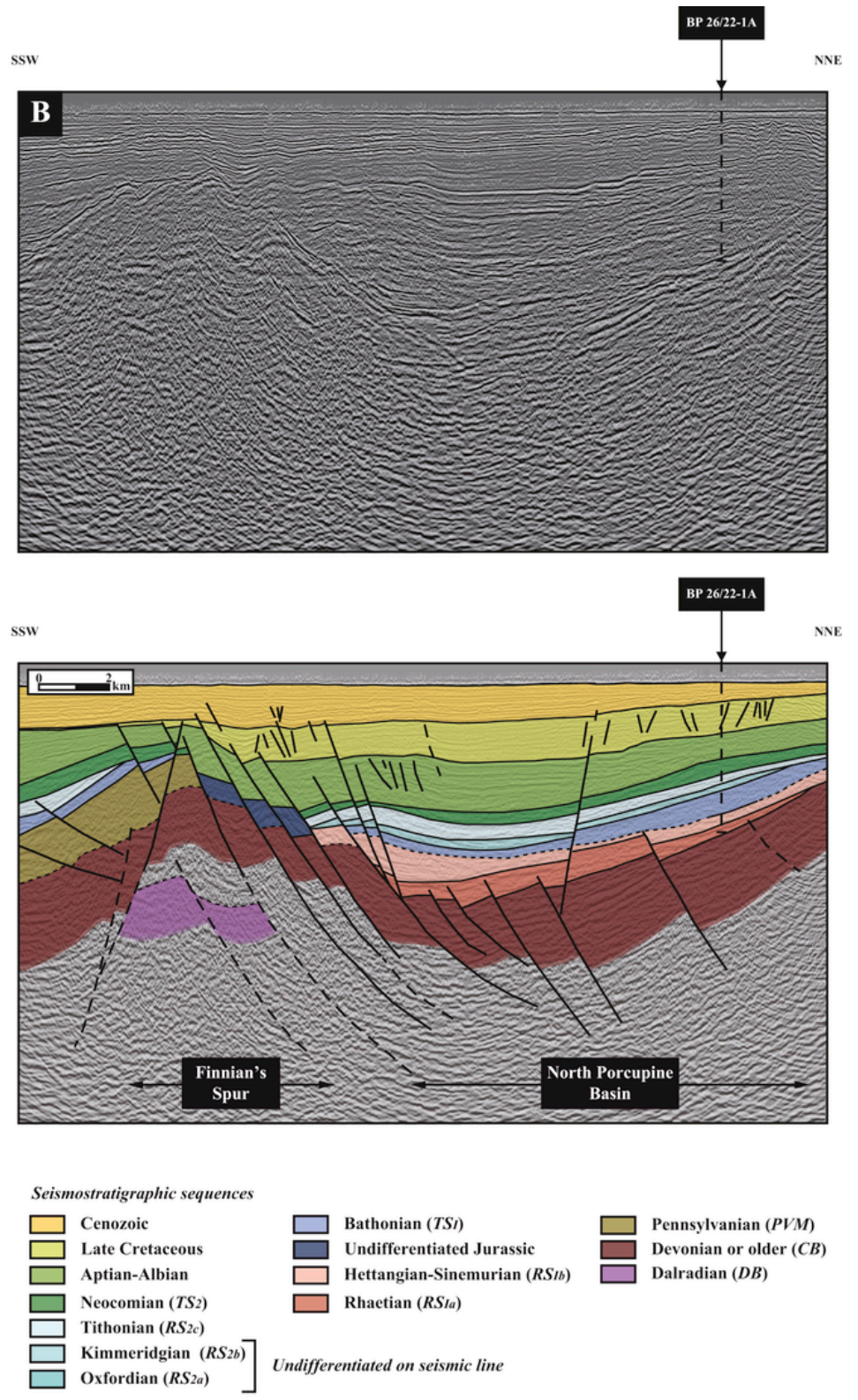

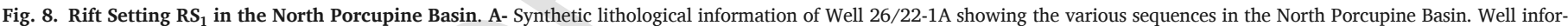

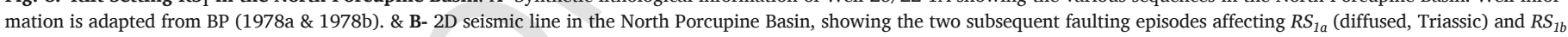
(localised, Lower Jurassic). Seismic line location can be seen on Fig. 9.

\subsection{Regional significance of extensional megasequences}

Conceptual views of the extensional development within single rifted basins traditionally focus on the fault system evolution and not necessarily on the stratigraphic record at the scale of a basin or of a passive margin (e.g. Leeder and Gawthorpe, 1987; Prosser, 1993; Ravnås and Steel, 1998; Purser and Bosence, 1998; Gawthorpe and Leeder, 2000). The most advanced regional models (e.g. Manatschal, 2004; Péron-Pinvidic and Manatschal, 2009) suggest discrete stages of evolution of a passive margin that reflects the lateral geometry of fault systems, with block faulting in the stretching domain and highly-rotated half-graben in the hyper-thinning domain oceanward (Fig. 14A). These models usually complete the rifting within 5-20 Myrs (Patton et al., 1994; Gupta et al., 1998; Sharp et al., 2000a, 2000b; Dawers and Underhill, 2000).
In the Porcupine Basin, deformation is organised in successive extensional episodes that are geographically and temporarily separated regionally. They combine an original orogenic collapse stage passing to classical stretching-thinning episodes. This reflects, on one hand, the large part of the extensional history of the Irish Atlantic Margin and follows, on the other hand, the classical stages of the formation of a passive margin, but on a $220 \mathrm{Myr}$ duration. It produces vertically-stacked megasequences bounded by synrift and postrift unconformities, and the relocation of the deformation during the extensional process. From our observation, we therefore discriminate extension driven by the orogenic collapse from the rifting sensu stricto. Collapse-generated extension, directly controlled by folds and thrusts of the Variscan Orogen, produced adjacent, slightly- or highly-rotated fault-blocks (Megasequence $P V M$, Fig. 6). In comparison, rifting forms numerous fault-blocks before extension focuses along the main bounding faults (Figs. 8 and 10). For both rift settings, this implies a diffuse rifting (high rota- 


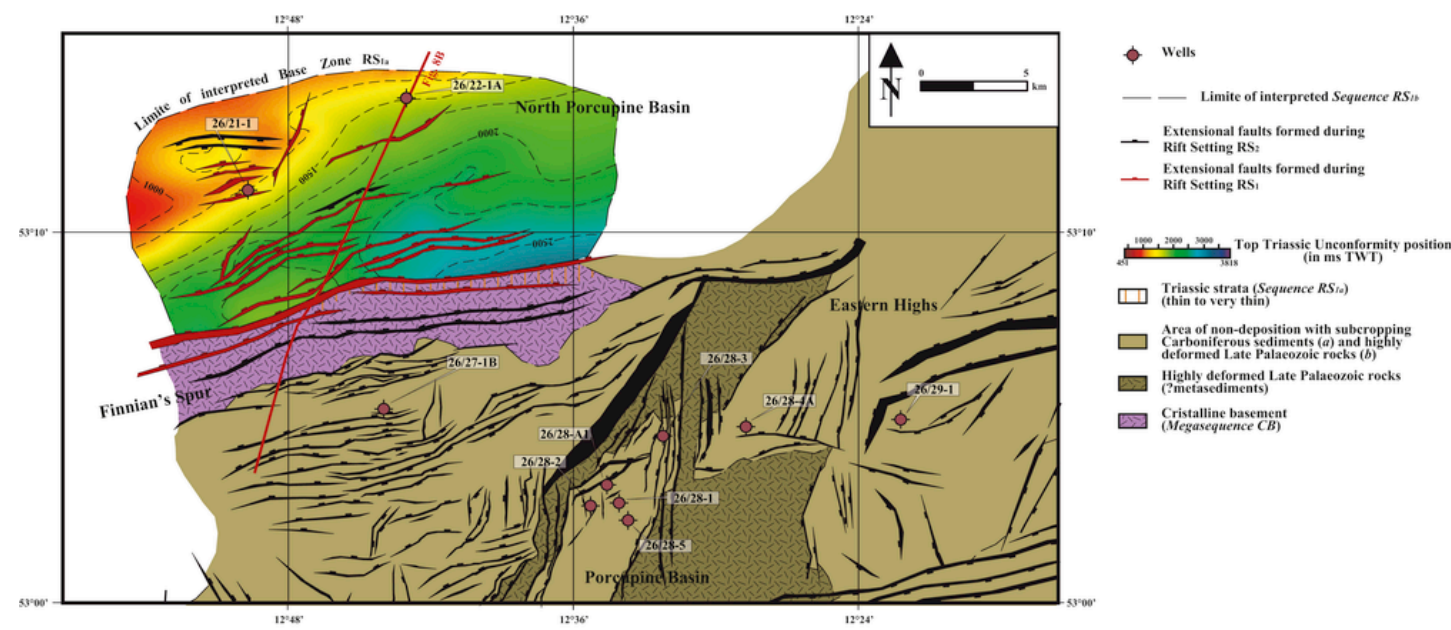

Fig. 9. Fault pattern in the North Porcupine Basin at the level of the Top Triassic Unconformity (Sequence $R S_{1 a}$ ).

tion) responsible of a rift megasequence $(R S)$, followed by a localised rifting (sag), responsible of the deposition of a transitional megasequence (TS). These transitions from orogenic collapse to the rifting and from diffuse to localised rifting produced regional unconformities, which articulate within the extensional megacycle concept in a basin and also into the evolution from stretching to hyper-thinning modes at a margin scale.

Deep seismic data in the Porcupine Basin (e.g. Reston et al., 2001 \& 2004; O'Reilly et al., 2006) show a striking crustal asymmetry, expressing the Variscan Front that was likely reactivated as a detachment to produce basin hyper-thinning (Fig. 14B). Similar observation in the adjacent Rockall Basin (e.g. Morewood et al., 2005) are interpreted as an evidence of the Iapetus Suture (i.e. Caledonian crust) while, in the Hatton Basin, the absence of hyper-thinning is interpreted as an effect of the thick Archean crust (i.e. Grenvillian terranes, Smith et al., 2005). At the same time, a generalised migration of the deformation as proposed in the literature reflects the re-arrangement of the margin from the Triassic to the Upper Cretaceous before Cenozoic breakup west of the Hatton Bank (e.g. Doré et al., 1999; Stoker et al., 2017). Somehow, this lateral configuration infers a crustal boudinage prior seafloor spreading.

Two different extensional modes are therefore proposed with, on one side, the initiation of the extension (orogenic collapse) and, on the other side, the crustal denudation (diffused rifting and localised hyper-stretching). Both modes are driven by the old crustal architecture and are sensitive to far-field forces. In that sense, extension may be regarded as a long-lived deformation period taking place with discontinuous events, just like in a classical passive margin formation (Fig. 14A), but our study also suggests a strong dependence to continental discontinuities (i.e. ancient orogenic structures) with an oceanward deformation migration at a margin scale (Fig. 14B). In addition, internal basin dynamics arranges in a diffuse and wide rift setting followed by deformation relocation along the main bounding faults towards the ocean. As a result, the stretching and the hyper-thinning stages are typically observed in rifted and transitional megasequences respectively, with a tectonic control along specific faults. In such a way, this succession episode implies extension on a 220Myr-duration with a succession of internal extensional megacycles of 15-20 Myrs, the last one leading to hyper-extension.

\section{Conclusion}

In this study, we have documented several extensional megacycles that successively developed in the Porcupine Basin over a long period of time evaluated at 220 Myrs (Carboniferous to Neocomian). Each ex- tensional megacycle is thought to represent a specific period encompassed by the Irish Atlantic Margin and may be defined by characteristic extensional megasequences bounded by precise syn- and postrift unconformities. These extensional megacycles are defined as such:

1 A late Palaeozoic event (Upper Carboniferous) shows rapid extension with little wedging and reactivates E-W and ENE-WSW trends of the southern boundary of the Caledonian Orogen and NE-SW and N-S faults along the northwestern part of the Variscan Orogen. The localisation of the deformation suggests a strong reactivation of orogenic structures in a general orogenic collapse. In particular, the Variscan crust, with a clear thin-skinned geometry, mostly controlled the formation of extensional fault blocks.

2 An early Triassic to Lower Jurassic extension $\left(\mathrm{RS}_{1}\right)$ took place in the North Porcupine Basin and did not propagate southward in the Porcupine Basin. It controlled the deposition of Megasequence $R S_{1}$, which shows diffuse deformation during the Rhaetian (Sequence $R S_{1 a}$ ) getting localised along the main boundary faults during the Hettangian-Sinemurian (Sequence $R S_{1 b}$ ). Synchronous to the Slyne-Erris formation, the rifting localised along Caledonian trends in a global NW-SE extensional direction. It corresponds to the southern extent of coeval Arctic rift system.

3 An Upper Jurassic-Neocomian extension $\left(\mathrm{RS}_{2}\right)$, characterising a strong rifting in the Porcupine Basin, controlled its v-shape development by reactivating NE-SW and N-S Variscan structures. To the north, it abutted the Caledonian crustal root avoiding extensional tectonics to propagate in the North Porcupine Basin. Related megasequences $R S_{2}$ and $T S_{2}$ deposited in several fault-blocks in a diffuse rift system, followed by more localised faulting along the bounding faults, which controlled a marine transgression at the scale of the basin. We therefore observe that Neocomian extension is a continuation of the Upper Jurassic rifting due to the North Atlantic opening, although faulting is progressively replaced by postrift thermal subsidence. This expresses the ultra-thinning and Moho rise in the south of the Porcupine Basin.

This apparent overlap of extensional settings reflects the formation of a typical Atlantic-type passive margin. It particularly shows a vertical stack of extensional megasequences, separated by characteristic unconformities bounding each extensional megacycles. Also, the structure of the continental crust has a dominant role in the initiation of the rifting (i.e. orogenic collapse) and then decreases as long as extension evolves. In this way, the Porcupine Basin opened as a typical rift propagator, with extension progressively migrating northward and oceanward, as well as differential uplift in the North Porcupine Basin and 


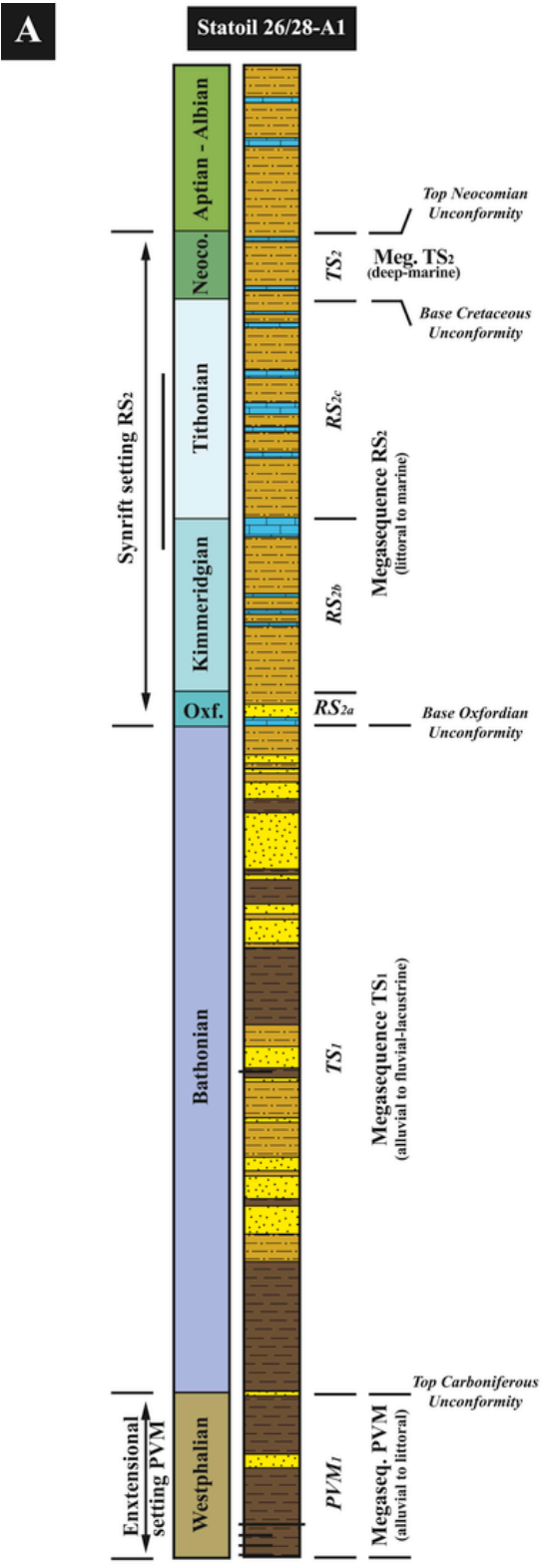
Top Mississippian
Unconformity

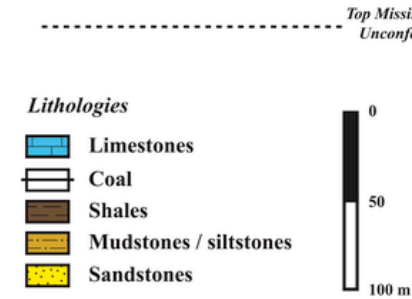

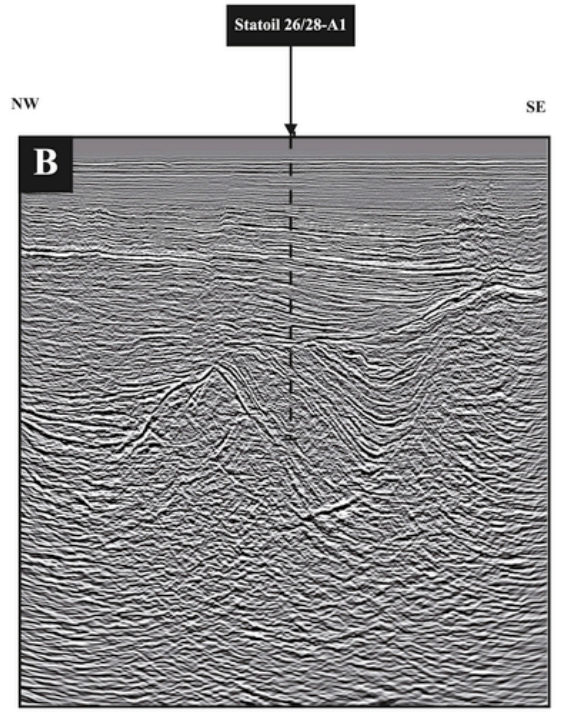

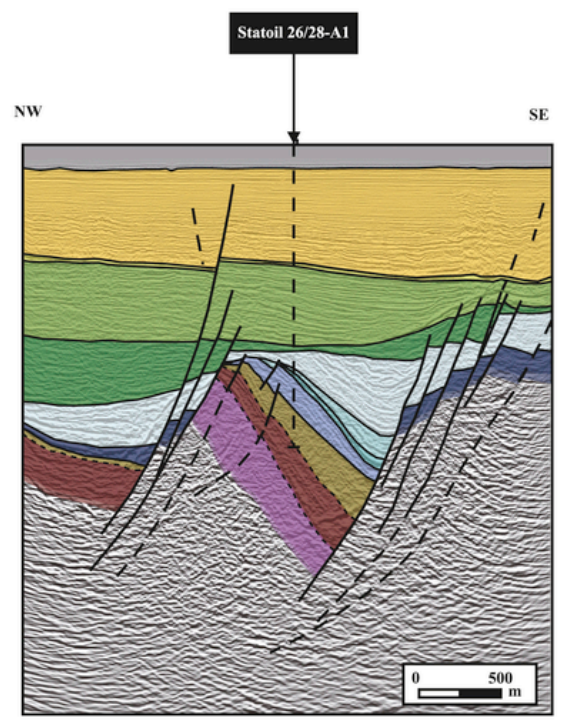

Seismostratigraphic sequences

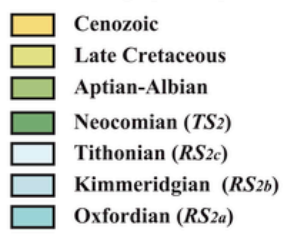

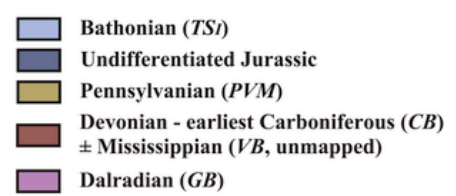

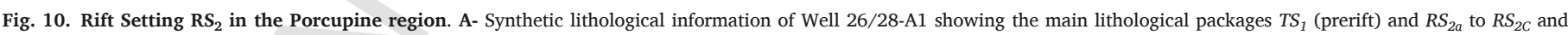

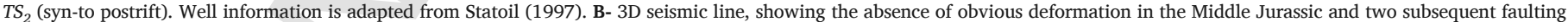
episodes affecting megasequences $R S_{2}$ (high rotation, possibly diffused, Upper Jurassic) and $T S_{2}$ (localised, Neocomian). Seismic line location can be seen on Fig. 11.

surrounding highs. This implies unsuccessful continental tears and may explain such a long-standing extensional history along the Irish Atlantic Margin.

\section{Uncited references}

Dancer et al., 1999; Tate and Dobson, 1989b.

\section{Acknowledgements}

This study was co-funded by Ecole Normale Supérieure (Paris, France) and the Irish Shelf Petroleum Studies Group (ISPSG, years 2005-2012) of the Irish Petroleum Infrastructure Programme (PIP). We specifically thank the Petroleum Affairs Division of the Department of Communications, Climate Action and Environment, Ireland, for giving 
Table 3

Well and seismic characteristics of unconformities associated with the rift system RS2 in the northern Porcupine region.

\begin{tabular}{|c|c|c|c|c|c|}
\hline $\begin{array}{l}\text { Stratigraphic } \\
\text { surface }\end{array}$ & $\begin{array}{l}\text { Abbreviated } \\
\text { name }\end{array}$ & Well tie & $\begin{array}{l}\text { Stratigraphic } \\
\text { formations } \\
\text { involved }\end{array}$ & $\begin{array}{l}\text { Seismic } \\
\text { megasequence }\end{array}$ & Seismic definition \\
\hline $\begin{array}{l}\text { Top Neocomian } \\
\text { Unconformity }\end{array}$ & TNU & $\begin{array}{l}\text { All wells } \\
\text { (except 26/ } \\
21-1 \text { ) } \\
26 / 21-1\end{array}$ & $\begin{array}{l}\text { Top: Aptian- } \\
\text { Albian } \\
\text { Bottom: } \\
\text { Neocomian } \\
\text { Top: Lower } \\
\text { Aptian } \\
\text { Bottom: } \\
\text { Barremian }\end{array}$ & $\begin{array}{l}\text { Megasequence } \\
\mathrm{TS}_{2}\end{array}$ & $\begin{array}{l}\text { High-amplitude reflector generally associated with onlaps } \\
\text { of Aptian-Albian reflectors }\end{array}$ \\
\hline $\begin{array}{l}\text { Base Cretaceous } \\
\text { Unconformity }\end{array}$ & BCU & $\begin{array}{l}\text { All wells with } \\
\text { Cretaceous } \\
\text { (except 26/ } \\
21-1 \text { ) } \\
26 / 21-1\end{array}$ & $\begin{array}{l}\text { Top: Lower } \\
\text { Cretaceous } \\
\text { Bottom: } \\
\text { Portlandian (or } \\
\text { older) } \\
\text { Top: Neocomian } \\
\text { Bottom: Lower } \\
\text { Jurassic }\end{array}$ & $\begin{array}{l}\text { Megasequence } \\
R S_{2}\end{array}$ & $\begin{array}{l}\text { High-amplitude reflector, with overlying Early Cretaceous } \\
\text { strata onlapping on truncated Upper Jurassic (or older) } \\
\text { sediments. }\end{array}$ \\
\hline $\begin{array}{l}\text { Base Oxfordian } \\
\text { Unconformity }\end{array}$ & BOU & $\begin{array}{l}\text { All wells with } \\
\text { Middle } \\
\text { Jurassic } \\
\text { (except 26/ } \\
27-1 \mathrm{~B}, 26 / \\
28-2 \text { \& 34/ } \\
\text { 15-1) } \\
26 / 27-1 \mathrm{~B} \\
\\
26 / 28-2 \text { \& 34/ } \\
15-1\end{array}$ & $\begin{array}{l}\text { Top: Oxfordian } \\
\text { (Zone } \mathrm{LC}_{\text {II }} \text { ) } \\
\text { Bottom: } \\
\text { Bathonian (Zone } \\
\mathrm{LC}_{\mathrm{I}} \text { ) } \\
\text { Top: Oxfordian } \\
\text { (Zone LC } \text { II) } \\
\text { Bottom: } \\
\text { Westphalian D } \\
\text { No } \\
\text { unconformities }\end{array}$ & $\begin{array}{l}\text { Megasequence } \\
\mathrm{TS}_{1}\end{array}$ & $\begin{array}{l}\text { Medium-, locally strong-amplitude reflector, with many } \\
\text { onlap and downlap patterns in overlying Zone } \mathrm{RS}_{\mathrm{IIb}} \text {. The } \\
\text { truncation of underlying reflectors of Zone } \mathrm{RS}_{\mathrm{II}} \text { is uneven. } \\
\text { Locally, the unconformity is associated with more } \\
\text { transparent strata. }\end{array}$ \\
\hline $\begin{array}{l}\text { Top } \\
\text { Carboniferous } \\
\text { Unconformity }\end{array}$ & TCU & $\begin{array}{l}26 / 21-1 \\
26 / 28-1,26 / \\
28-2,26 / 28-3 \\
26 / 27-1 B, 26 / \\
28-4 A, 26 / \\
29-1 \\
26 / 30-1\end{array}$ & $\begin{array}{l}\text { Top: Triassic } \\
\\
\text { Bottom: } \\
\text { Westphalian B } \\
\text { Top: Middle } \\
\text { Jurassic } \\
\text { Bottom: } \\
\text { Stephanian } \\
\text { Top: Middle } \\
\text { Jurassic } \\
\\
\text { Bottom: } \\
\text { Westphalian C } \\
\text { Top: Middle } \\
\text { Jurassic } \\
\text { Bottom: } \\
\text { Westphalian B }\end{array}$ & $\begin{array}{l}\text { Megasequence } \\
\mathrm{VB}_{2}\end{array}$ & $\begin{array}{l}\text { Usually moderate- to high-amplitude reflector (especially in } \\
\text { the centre of the basin). Many truncated reflectors are } \\
\text { observed throughout the basin, the surface being often } \\
\text { located above high-amplitude, continuous reflectors. } \\
\text { Sometimes, it is associated with more transparent to } \\
\text { chaotic strata and basement. }\end{array}$ \\
\hline
\end{tabular}

access to the well and processed seismic data, as well as Professor Patrick M. Shannon from University College Dublin (Ireland) and Professor Jacques Déverchère from Université Bretagne Occidentale
(France) for thoughtful discussions. We also would like to deeply thank Professor Tim Minshull and Doctor Laurent Gernigon for their constructive comments during the review. 


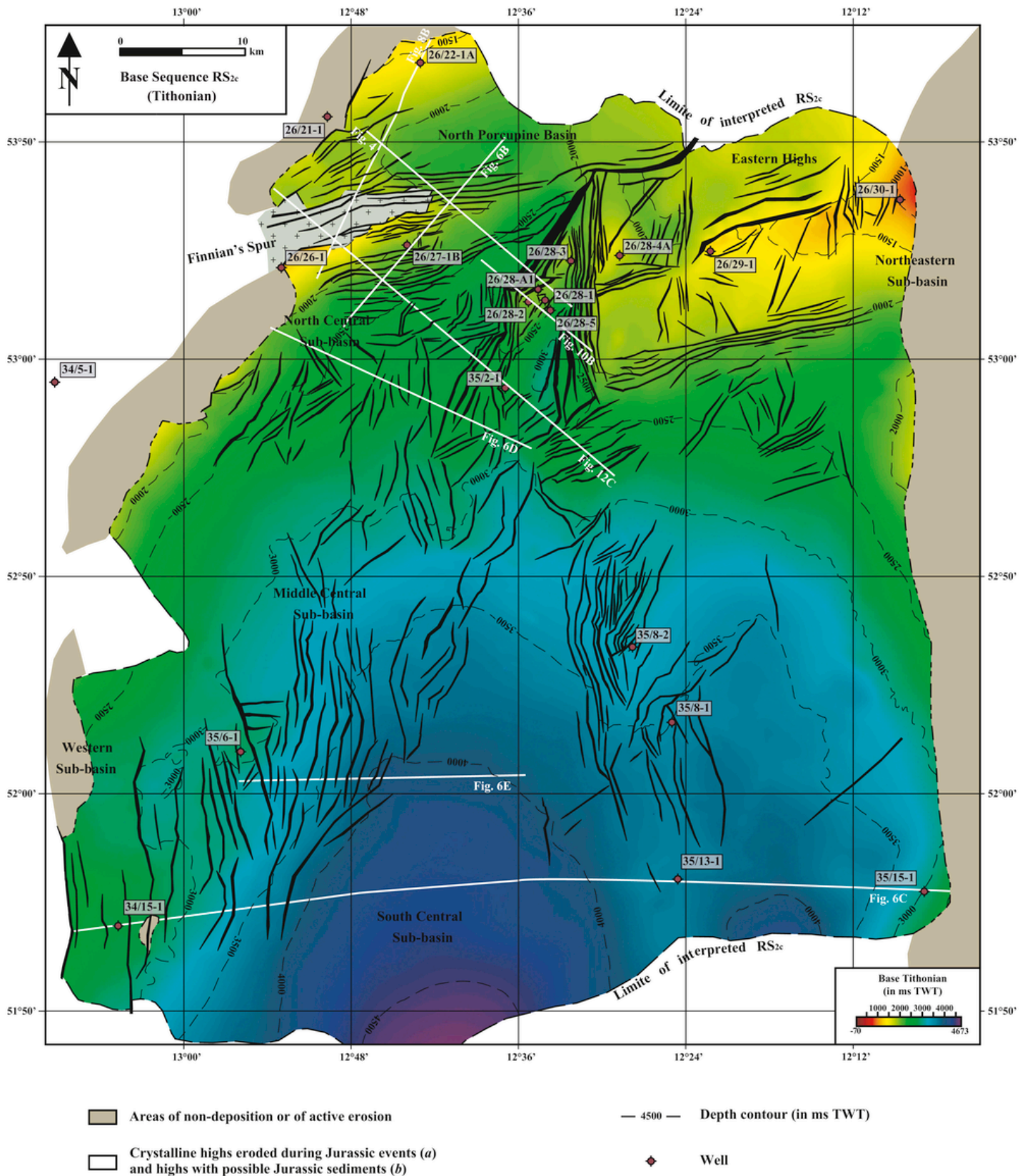

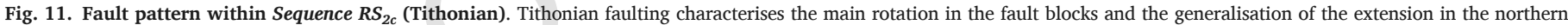
Porcupine region. Note the $\mathrm{v}$-shape drawn by the various faults. 


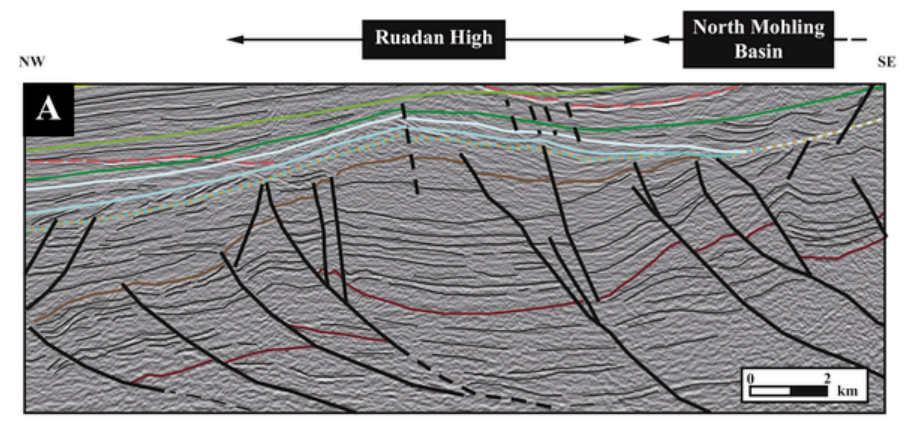

Interpreted surfaces

_ Base Cenozoic Disconformity

_ Base Upper Cretaceous Unconformity

_ Top Neocomian Unconformity

— Base Cretaceous Unconformity

Base Portlandian Disconformity

- Base Kimmeridgian Disconformity

_ Base Oxfordian Disconformity

_ Base Middle Jurassic Unconformity

_ Top Autunian Unconformity

_ Top Carboniferous Unconformity

__ Top Mississippian Unconformity

_ Top Devonian Unconformity
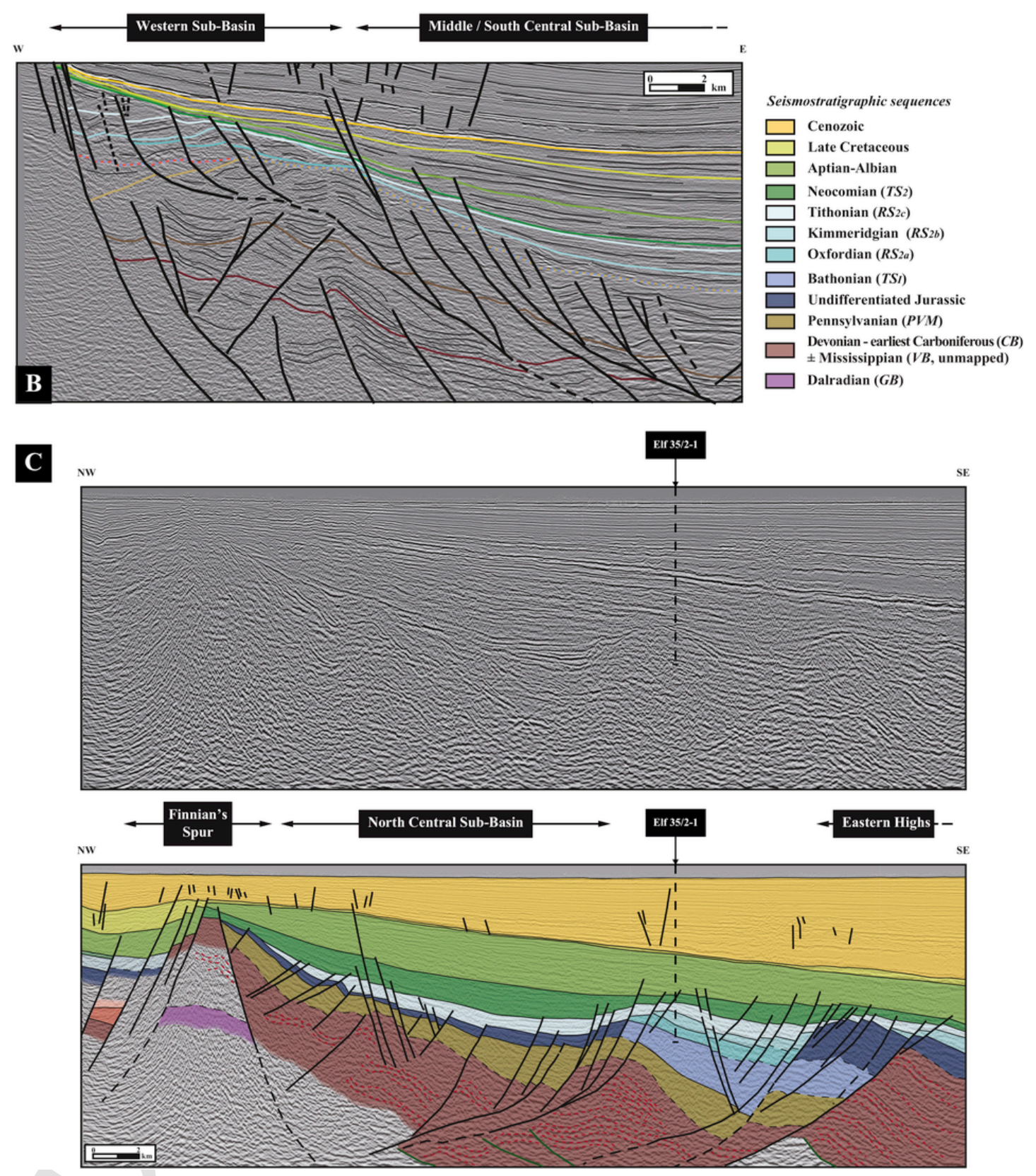

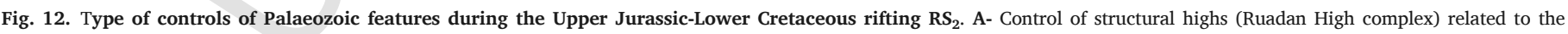

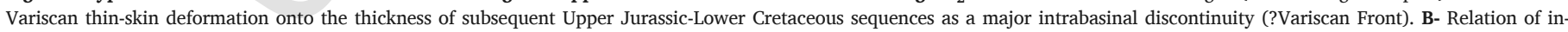

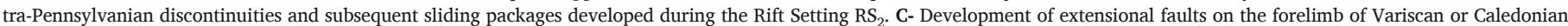

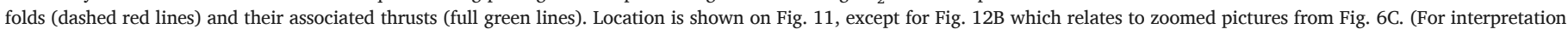
of the references to colour in this figure legend, the reader is referred to the Web version of this article.) 

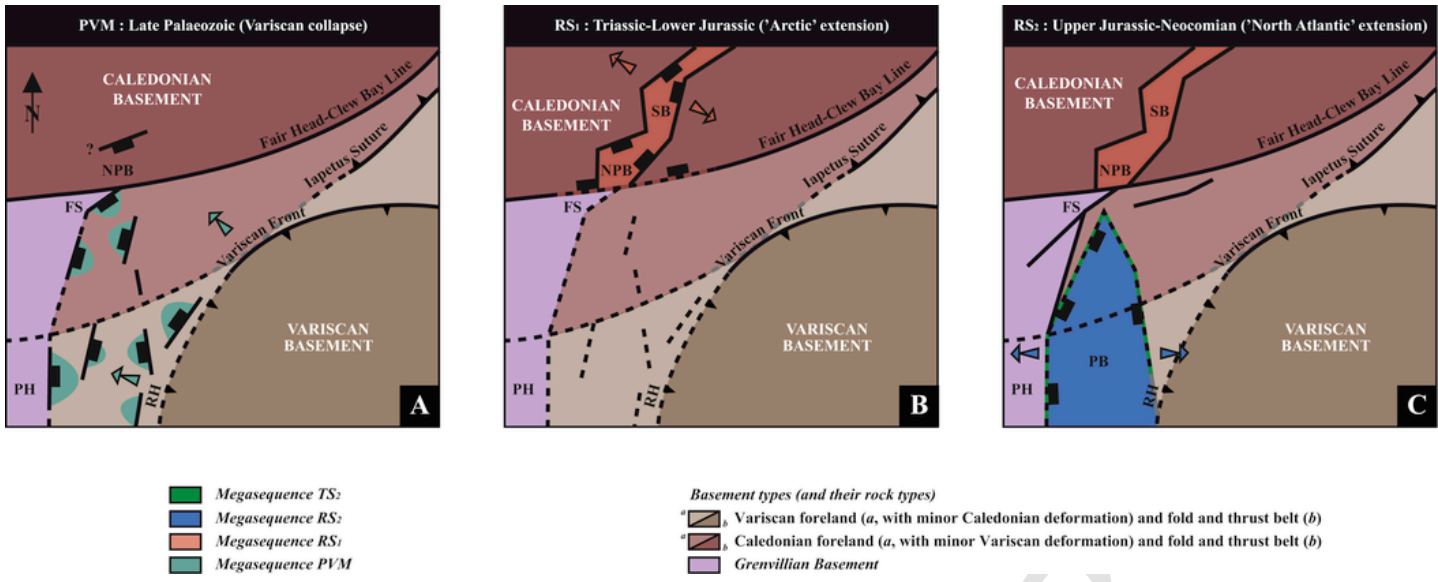

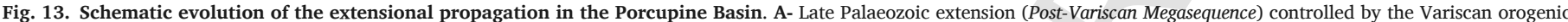

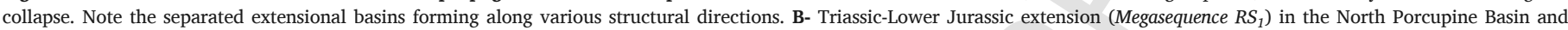

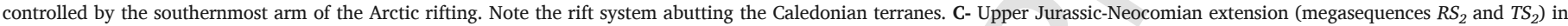

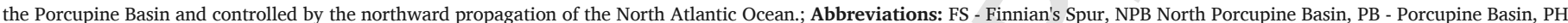
- Porcupine High, RH - Ruadan High, SB - Slyne Basin.

A
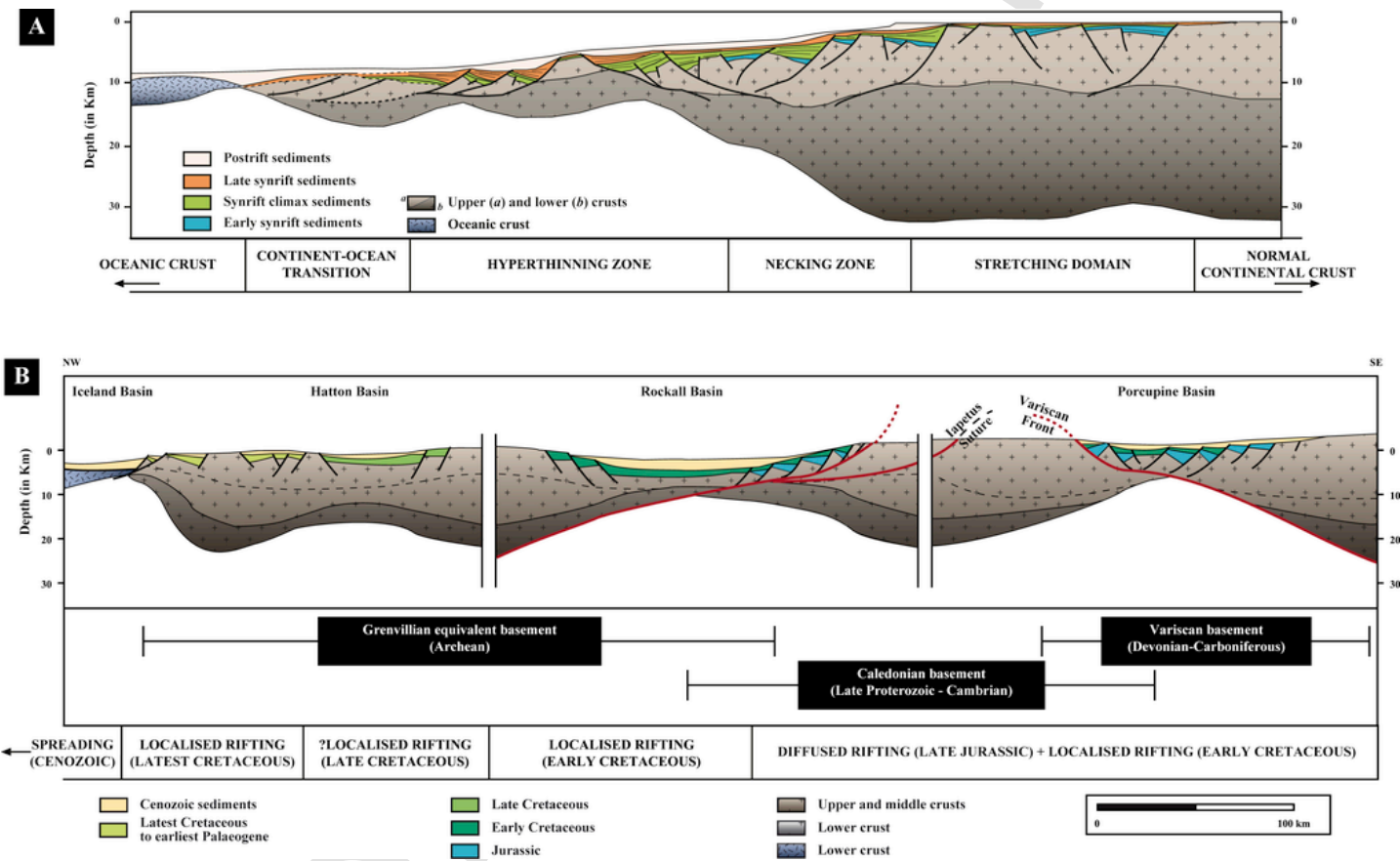

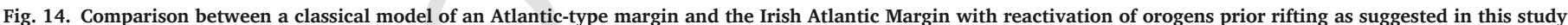

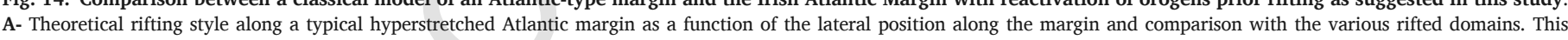

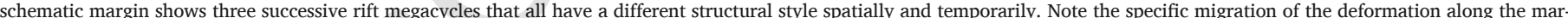

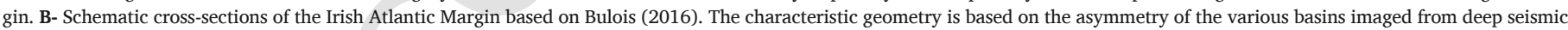

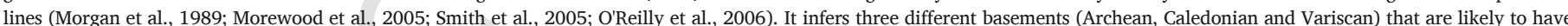

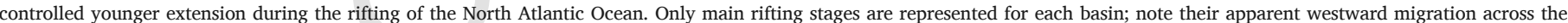
margin.

\section{References}

O'Reilly, B.M., Hauser, F., Ravaut, C., Shannon, P.M., Readman, P.W., 2006. Crustal thinning, mantle exhumation and serpentinization in the Porcupine Basin, offshore Ireland: evidence from wide-angle seismic data. J. Geol. Soc. Lond. 163, 775-787.

Auffret, A., Pastouret, L., Cassat, G., De Charpal, O., Cravatte, J., Guennoc, P., 1979. Dredged rocks from the armorican and celtic margins. In: Initial Reports of the Deep Sea Drilling Project, vol. 68, U.S. Government, pp. 473-491.

Auffret, A., Auzende, J.M., Cousin, M., Coutelle, A., Dobson, M., Geoghegan, M., Masson, D., Rolet, J., Vaillant, P., Groupe CYAPORC, 1987. Géologie des Escarpements de Porcupine et de Goban (N.E. Atlantique). Résultats de la campagne de plongée CYAPORC. Note du Groupe CYAPORC. C. R. Acad. Sci. 304, 1003-1008.
Badley, M.E., Egeberg, T., Nipen, O., 1984. Development of rift basins illustrated by the structural evolution of the Oseberg feature, Block 30/6, offshore Norway. J. Geol. Soc. Lond. 141, 639-649.

Badley, M.E., Price, J.D., Rambech Dahl, C., Agdestein, T., 1988. The structural evolution of the northern Viking Graben and its bearing upon extensional modes of basin formation. J. Geol. Soc. Lond. 145, 455-472.

Ballèvre, M., Bosse, V., Dabard, M.P., Ducassou, C., Fourcade, S., Paquette, J.L., Peucat, J.J., Pitra, P., 2013. Histoire Géologique du Massif Armoricain : actualité de la recherche. Bulletin de la Société Minéralogique de Bretagne 10-11, 5-96.

Bartholomew, I.D., Peters, J.M., Powell, C.M., 1993. Regional structural evolution of the North Sea: oblique slip and the reactivation of basement lineaments. In: Parker, J.R. (Ed.), Petroleum Geology of Northwest Europe: Proceedings of the 4th Conference. The Geological Society, London, pp. 1109-1122.

BIRPS, ECORS, 1986. Deep seismic reflection profiling between England, France and Ireland. J. Geol. Soc. Lond. 143, 45-52. 
BP, 1978a. Well BP 26/22-1A Composite Log. BP Petroleum Development Ltd, Irish Banch, (in-house publication).

BP, 1978b. Well BP 26/22-1 \& 26/22-1A Completion Report. BP Petroleum Development Ltd, Irish Banch, (in-house publication).

BP, 1979a. Well BP 26/28-1 Composite Log. BP Petroleum Development Ltd, Irish Banch, prepared by Simpson I.R., Pratt, D.N. \& Webster, D. (in-house publication).

BP, 1979b. Well BP 26/28-1 Completion Report. BP Petroleum Development Ltd, Irish Banch, (in-house publication)

BP, 1980a. Well BP 26/28-2 Composite Log. BP Petroleum Development Ltd, Irish Banch, prepared by Rainey, D.I. \& Fischer, W.C. (in-house publication).

BP, 1980b. Well BP 26/28-2 Geological Completion Report. BP Petroleum Development Ltd, Irish Banch, prepared by Rainey, D.I. \& Fischer, W.C. (in-house publication).

BP, 1981a. Well BP 26/28-3 Composite Log. BP Petroleum Development Ltd, Irish Banch, prepared by Gidman, J., Heinrich, R. \& Fischer, W.C. (in-house publication).

BP, 1981b. Well BP 26/28-2 Geological Completion Report. BP Petroleum Development Ltd, Irish Banch, prepared by Gidman, J. (in-house publication).

BP, 1981c. Well BP 26/28-4A Composite Log. BP Petroleum Development Ltd, Irish Banch, prepared by Crawley, J. \& Cottle, J. (in-house publication).

BP, 1982a. Well BP 26/28-4A Evaluation Report. BP Petroleum Development Ltd, Irish Banch, prepared by Cottle, J. \& Evans, T.G. (in-house publication).

BP, 1982b. Well BP 26/29-1 Composite Log. BP Petroleum Development Ltd, Irish Banch, prepared by Richards, D.P.J. \& Fischer, W.C. (in-house publication).

BP, 1982c. Well BP 26/29-1 Geological Completion Report. BP Petroleum Development Ltd, Irish Banch, prepared by Richards, D.P.J., Corrigan, K. \& Fischer, W.C. (in-house publication).

Buckley, J.S., Bailey, R.J., 1975. A free air gravity anomaly contour map of the Irish continental margin. Mar. Geophys. Res. 2, 185-194.

Bulois, C., 2016. Marges polyriftées : réactivation et conditions aux limites. Exemples de la Mer de Corail (Papouasie Nouvelle Guinée) et du Bassin de Porcupine (Irlande). PhD thesis Université de Bretagne Occidentale - Ecole Normale Supérieure de Paris, 519.

Bulois, C., Pubellier, M., Chamot-Rooke, N., Delescluse, M., 2017. Successive rifting events in marginal basins: the example of the coral Sea region (Papua New Guinea). Tectonics 37, 3-29.

Burke, K., Dewey, J.F., 1974. Hot spots and continental breakup: implications for collisional orogeny. Geology 2, 57-60

Calvès, G., Torvela, T., Huuse, M., Dinkelman, M.G., 2012. New evidence for the origin of the porcupine median volcanic ridge: early cretaceous volcanism in the Porcupine basin, atlantic margin of Ireland. G-cubed 13, Q06001.

Chen, C., Watremez, L., Prada, M., Minshull, T., Edwards, R., O'Reilly, B., Reston, T., Wagner, G., Gaw, V., Klaschen, D., Shannon, P., 2017. From continental hyperextension to seafloor spreading: new insights on the Porcupine basin from wide-angle seismic data. EGU 2017. In: Geophysical Research Abstracts. EGU, Vienna, EGU2017-7109.

Chen, C., et al., submitted. From Continental Hyperextension to Seafloor Spreading: New Insights on the Porcupine Basin from Wide-angle Seismic Data. J. Geophy. Res.

Chevron, 1981. Well Chevron 26/27-1B Final Well Report. Chevron Petroleum (U.K.) Ltd., (in-house publication).

Chevron, 1981. Well Chevron 26/27-1B Composite Log. Chevron Petroleum (U.K.) Ltd, prepared by Fell, D., Hancock, F.R.P., Hayes, F.I. (in-house publication).

Chew, D., 2009. Grampian orogeny. In: Holland, C.H., Sanders, I.S. (Eds.), The Geology of Ireland. Dunedin Academic Press Ltd, Edinburgh, pp. 69-93.

Chew, D., Stillman, C.J., 2009. Late caledonian orogeny and magmatism. In: Holland, C.H., Sanders, I.S. (Eds.), The Geology of Ireland. Dunedin Academic Press Ltd, Edinburgh, pp. 143-173.

Cocks, L.R.M., Torsvik, T.H., 2006. European geography in a global context from the Vendian to the end of the Palaeozoic. In: In: Gee, D.G., Stephenson, R.A. (Eds.), European Lithosphere Dynamics. Memoirs, vol. 32, The Geological Society, London, pp. 83-95.

Cook, D.R., 1987. The Goban Spur: exploration in a deepwater frontier basin. In: Brooks, J., Glennie, K.W. (Eds.), Petroleum Geology of North-West Europe: Proceedings of the 3rd Conference. Trotman Ltd, London, pp. 623-632.

Cooper, M.A., Collins, D., Ford, M., Murphy, F.X., Trayner, P.M., 1984. Structural style, shortening estimates and the thrust front of the Irish Variscides. In: In: Hutton, D.H.W., Sanderson, D.J. (Eds.), Variscan Tectonics of the North Atlantic Region. Special Publication, vol. 14, The Geological Society, London, pp. 167-175.

Cooper, M.A., Collins, D., Ford, M., Murphy, F.X., Trayner, P.M., O'Sullivan, M., 1986. Structural evolution of the Irish Variscides. J. Geol. Soc. Lond. 143, 53-61.

Corfu, F., Gasser, D., Chew, D., 2014. New perspectives on the Caledonides of Scandinavia and related areas: introduction. In: In: Corfu, F., Gasser, D., Chew, D. (Eds.), New Perspectives on the Caledonides of Scandinavia and Related Areas. Special Publications, vol. 390, The Geological Society, London, pp. 1-8.

Croker, P.F., 1995. The Clare Basin: a geological and geophysical outline. In: In: Croker, P.F., Shannon, P.M. (Eds.), The Petroleum Geology of Ireland's Offshore Basins. Special Publications, vol. 93, The Geological Society, London, pp. 327-339.

Croker, P.F., Klemperer, S.L., 1989. Structure and stratigraphy of the Porcupine basin : relationships to deep crustal structure and the opening of The north atlantic. In: Tankard, A.J., Balkwill, H.R. (Eds.), Extensional Tectonics and Stratigraphy of the North Atlantic Margins. The American Association of Petroleum Geologists \& The Canadian Geological Foundation, Tulsa, pp. 445-459.

Croker, P.F., Shannon, P.M., 1987. The evolution and hydrocarbon prospectivity of the Porcupine Basin, Offshore Ireland. In: Brooks, J., Glennie, K.W. (Eds.), Petroleum Geology of North-West Europe: Proceedings of the 3rd Conference. Trotman Ltd, London, pp. 633-642.
Daly, J.S., 1996. Pre-caledonian history of the annagh gneiss complex, north-western Ireland, and correlation with Laurentia-Baltica. Ir. J. Earth Sci. 15, 5-18.

Daly, J.S., 2009. Precambrian. In: Holland, C.H., Sanders, I.S. (Eds.), The Geology of Ireland. Dunedin Academic Press Ltd, Edinburgh, pp. 7-42.

Daly, J.S., Heaman, L.M., Fitzgerald, R.C., Menuge, J.F., Brewer, T.S., Morton, A.C., 1995 Age and crustal evolution of crystalline basement in western Ireland and Rockall. In: In: Croker, P.F., Shannon, P.M. (Eds.), The Petroleum Geology of Ireland's Offshore Basins. Special Publications, vol. 93, The Geological Society, London, pp. 433-434.

Dancer, P.N., Algar, S.T., Wilson, I.R., 1999. Structural evolution of the Slyne trough. In: Fleet, A.J., Boldy, S.A.R. (Eds.), Petroleum Geology of Northwest Europe: Proceedings of the 5th Conference. The Geological Society, London, pp. 445-453.

Davies, S.J., Guion, P.D., Gutteridge, P., 2012. Carboniferous sedimentation and volcan ism on the laurussian margin. In: Woodcock, N.H., Strachan, R.A. (Eds.), Geological History of Britain and Ireland, second ed. John Wiley \& Sons, Ltd, Chichester, UK, pp. 227-271.

Dawers, N.H., Underhill, J.R., 2000. The role of fault interaction and linkage in controlling synrift stratigraphic sequences: late Jurassic, Statfjord east area, northern north sea. AAPG (Am. Assoc. Pet. Geol.) Bull. 84 (1), 45-64.

de Graciansky, P.C., Poag, C.W., Cunningham Jr., R., Loubère, P., Masson, D., Mazzulo, J.M., Montadert, L., Muller, C., Otsuka, K., Reynolds, L.A., Sigal, J., Snyder, S.W., Townsend, H.A., Vaos, S.P., Waples, D., 1985. The Goban Spur transect: geologic evolution of a sediment-starved passive continental margin. GSA Bull. 96 (1), 58-76.

Deminex, 1977. Well Deminex 34/15-1 Composite Log. Deminex Ireland Ltd., prepared by Hill, W.O.R. (in-house publication).

Doré, A.G., Lundin, E.R., Fichler, C., Olesen, O., 1997. Patterns of basement structure and reactivation along the NE Atlantic margin. J. Geol. Soc. Lond. 154, 85-92.

Doré, A.G., Lundin, E.R., Jensen, L.N., Birkeland, , Eliassen, P.E., Fichler, C., 1999. Principal tectonic events in the evolution of the northwest European Atlantic Margin. In: Fleet, A.J., Boldy, S.A.R. (Eds.), Petroleum Geology of Northwest Europe: Proceedings of the 5th Conference. The Geological Society, London, pp. 41-61.

Elf Aquitaine, 1976. Well Elf 34/5-1 Composite Log. Elf Aquitaine Ireland Ltd, prepared by Croisile, M. (in-house publication).

Elf Aquitaine, 1981. In: Well Elf 34/5-1 Completion Report. Elf Aquitaine Ireland Ltd, prepared by Renoux, J. \& Croisile, M. (in-house publication).

Fraser, A.J., Gawthorpe, R.L., 1990. Tectono-stratigraphic development and hydrocarbon habitat of the Carboniferous in northern England. In: Hardman, R.F.P., Brooks, J. (Eds.), Tectonic Events Responsible for Britain's Oil and Gas Reserves. The Geological Society of London, London, pp. 49-86.

Fraser, A.J., Gawthorpe, R.L., 2003. An Atlas of Carboniferous Basin Evolution in Northern England. Memoir, vol. 28, The Geological Society of London, London.

Frostick, L.E., Steel, R.J., 1993. Sedimentation in divergent plate-margin basins. In: Frostick, L.E., Steel, R.J. (Eds.), Tectonic Controls and Signatures in Sedimentary Successions. International Association of Sedimentologists, pp. 111-128.

Gagnevin, D., Haughton, P.D.W., Whiting, L., Saqab, M.M., 2017. Geological and geophysical evidence for a mafic igneous origin of the Porcupine Arch, offshore Ireland. J. Geol. Soc. 175 (2), 210-228.

Gawthorpe, R.L., Leeder, M.R., 2000. Tectono-sedimentary evolution of active extensional basins. Basin Res. 12, 195-218.

Gernigon, L., Brönner, M., Roberts, D., Olesen, O., Nasuti, A., Yamakasi, T., 2014. Crustal and basin evolution of the southwestern Barents Sea: from Caledonian orogeny to continental breakup. Tectonics 33, 347-373.

Gill, W.D., 1979. Syndepositional Sliding and Slumping in the West Clare Namurian basin, Ireland. GSI Special Paper. Geological Survey of Ireland, Dublin.

Grow, J.A., Hutchinson, D.R., Klitgord, K.D., Dillon, W.P., Schlee, J.S., 1983. Representative multichannel seismic profiles over the U.S. Atlantic margin, in seismic expression of structural styles. In: In: Bally, A.W. (Ed.), Studies in Geology, vol. 15, American Association of Petroleum Geologists, pp. 1-19.

Gulf, 1979. Well Gulf 26/21-1 Composite Log. Gulf Oil (Ireland) Ltd, prepared by Bignell, R.D. (in-house publication).

Gulf, 1980. Well Gulf 26/21-1 Completion Report. Gulf Oil (Ireland) Ltd, prepared by Bignell, R.D. \& Black, J.A. (in-house publication).

Gupta, S., Cowie, P.A., Dawers, N.H., Underhill, J.R., 1998. A mechanism to explain rift-basin subsidence and stratigraphic patterns through fault-array evolution. Geology 26 (7), 595-598.

Hutton, D.H.W., Aslop, G.I., 2004. Evidence of a major neoproterozoic unconformity within the dalradian Supergroup of NW Scotland. J. Geol. Soc. Lond. 161, 629-640.

Jacob, A.W.B., Shannon, P.M., Makris, J., Hauser, F., Vogt, U., O'Reilly, B.M., 1995. An overview of the results of the RAPIDS seismic project, North Atlantic. In: In: Croker, P.F., Shannon, P.M. (Eds.), The Petroleum Geology of Ireland's Offshore Basins. Special Publications, vol. 93, The Geological Society, London, pp. 429-431.

Johnson, H., Ritchie, J.D., Gatliff, R.W., Williamson, J.P., Cavill, J., Bulat, J., 2001. Aspects of the structure of the Porcupine and Porcupine Seabight basins as revealed from gravity modelling of regional seismic transects. In: In: Shannon, P.M., Haughton, P.D.W., Corcoran, D.V. (Eds.), The Petroleum Exploration of Ireland's Offshore Basins. Special Publications, vol. 188, Geological Society, London, pp. 265-274.

Johnston, S., Doré, A.G., Spencer, A.M., 2001. The Mesozoic evolution of the southern North Atlantic region and its relationship to basin development in the south Porcupine Basin, offshore Ireland. In: In: Shannon, P.M., Haughton, P.D.W., Corcoran, D.V. (Eds.), The Petroleum Exploration of Ireland's Offshore Basins. Special Publications, vol. 188, Geological Society, London, pp. 237-263. 
Jones, D.W., Underhill, J.R., 2011. Structural and stratigraphic evolution of the Connemara discovery, Northern Porcupine Basin: significance for basin development and petroleum prospectivity along the Irish Atlantic Margin. Petrol. Geosci. 17, 365-384.

Klemperer, S.L., 1989. Seismic reflection evidence for the location of the Iapetus suture west of Ireland. J. Geol. Soc. Lond. 146, 409-412.

Klemperer, S.L., Ryan, P.D., Snyder, D.B., 1991. A deep seismic reflection transect across the Irish Caledonides. J. Geol. Soc. Lond. 148, 149-164.

Lambert, R.S., McKerrow, W.S., 1976. The grampian orogeny. Scot. J. Geol. 12, 271-292.

Leeder, M.R., Gawthorpe, R.L., 1987. Sedimentary models for extensional tilt-block/ half-graben basins. In: Coward, M.P., Dewey, J.F., Hancock, P.L. (Eds.), Continental extensional Tectonics. Geological Society of London, London, pp. 139-152.

MacDonald, H., Allan, P.M., Lovell, J.P.B., 1987. Geology of oil accumulation in block 26/ 28, Porcupine basin, offshore Ireland. In: Brooks, J., Glennie, K.W. (Eds.), Petroleum Geology of North-West Europe: Proceedings of the 3rd Conference. Trotman Ltd, London, pp. 643-651.

Makris, J., Egloff, R., Jacob, A.W.B., Mohr, P., Murphy, T., Ryan, P., 1988. Continental crust under the southern Porcupine Seabight west of Ireland. Earth Planet Sci. Lett. 89, 387-397.

Manatschal, G., 2004. New models for evolution of magma-poor rifted margins based on a review of data and concepts from West Iberia and the Alps. Int. J. Earth Sci. 93, 432-466.

Masson, D.G., Miles, P.R., 1986. Structure and development of the Porcupine Seabight sedimentary basin, offshore Southwest Ireland. Bull. Am. Assoc. Pet. Geol. 70, 563-584.

Masson, D.G., Miles, P.R., Max, M.D., Scrutton, R.A., Inamdar, D.D., 1985. A Free-air Gravity Anomaly Map of the Irish Continental Margin and a New Gravity Model across the Southern Porcupine Seabight. Report Series RS 85/4 Geological Survey of Ireland, Dublin.

Masson, D.G., Dobson, M.R., Auzende, J.M., Cousin, M., Coutelle, A., Rolet, J., Vaillant, P., 1989. Geology of porcupine bank and goban Spur, northeastern atlantic - preliminary result of the CYAPORC submersible cruise. Mar. Geol. 87, 105-119.

Max, M.D., 1978. Tectonic control of offshore sedimentary basins to the north and west of Ireland. J. Petrol. Geol. 1, 103-110.

Max, M.D., Inamdar, D.D., MacIntyre, T., 1982. Compilation Magnetic Map: the Irish Continental Shelf and Adjacent Areas. Report Series RS 82/2 Geological Survey of Ireland, Dublin.

McCann, T., Shannon, P.M., Moore, J.G., 1995. Fault styles in the Porcupine Basin, offshore Ireland: tectonic and sedimentary rocks. In: In: Croker, P.F., Shannon, P.M. (Eds.), The Petroleum Geology of Ireland's Offshore Basins. Special Publications, vol. 93, The Geological Society, London, pp. 371-383.

McKerrow, W.S., MacNiocaill, C., Dewey, J.F., 2000. The caledonian orogeny revisited. J. Geol. Soc. Lond. 157, 1149-1154.

Miller, J.A., Roberts, D.A., Dearnley, R., 1973. Precambrian rocks drilled from the Rockall bank. Nature 244, 21-23.

Mitchum, R., Vail, P., Sangree, J., 1977. Seismic stratigraphy and global changes of sea level; Part 6, Stratigraphic interpretation of seismic reflection patterns in depositional sequences. In: Payton, C.E. (Ed.), Seismic Stratigraphy; Applications to Hydrocarbon Exploration. AAPG Memoir, pp. 117-133.

Moore, J.G., 1992. A syn-rift to post-rift transition sequence in the Main Porcupine Basin, offshore western Ireland. In: In: Parnell, J. (Ed.), Basins on the Atlantic Seaboard: Petroleum Geology, Sedimentology and Basin Evolution. Special Publications, vol. 62, The Geological Society, London, pp. 333-349.

Morewood, N.C., MacKenzie, G.D., Shannon, P.M., O'Reilly, B.M., Readman, P.W., Makris, J., 2005. The crustal structure and regional development of the Irish Atlantic Margin region. In: Doré, A.G., Vining, B.A. (Eds.), Petroleum Geology: North-West Europe and Global Perspectives - Proceedings of the 6th Petroleum Geology Conference. The Geological Society, London, pp. 1023-1033.

Morgan, J.V., Barton, P.J., White, R.S., 1989. The Hatton Bank continental margin-III. Structure from wide-angle OBS and multichannel seismic refraction profiles. Geophys. J. Int. 98, 367-384.

Morton, A.C., Taylor, P.N., 1991. Geochemical and isotopic constraints on the nature and age of basement rocks from the Rockall Bank, NE Atlantic. J. Geol. Soc. Lond. 148, 631-634.

Naylor, D., Anstey, N.A., 1987. A reflection seismic study of the Porcupine Basin, offshore west Ireland. Ir. J. Earth Sci. 8, 187-210.

Naylor, D., Shannon, P.M., 2009. Geology of offshore Ireland. In: Holland, C.H., Sanders, I.S. (Eds.), The Geology of Ireland. Dunedin Academic Press Ltd, Edinburgh, pp. 405-460.

Naylor, D., Shannon, P.M., 2011. Petroleum Geology of Ireland, first ed. Dunedin Academic Press Ltd, Edinburgh.

Naylor, D., Shannon, P., Murphy, N., 1999. Irish Rockall Basin Region - a Standard Structural Nomenclature System, first ed. Petroleum Affairs Division, Special Publication 1/99, Dublin.

Naylor, D., Shannon, P., Murphy, N., 2002. Porcupine-goban Region - a Standard Structural Nomenclature System, first ed. Petroleum Affairs Division, Special Publication 1/02, Dublin.

Nirrengarten, M., Manatschal, G., Tugend, J., Kuznir, N., Sauter, D., 2017. Kinematic evolution of the southern North Atlantic: implications for the formation of hyper-extended rift systems: kinematic of hyper-extended rift systems. Tectonics 37.

PAD, 2006. Petroleum Systems Analysis of the Rockall and Porcupine Basins Offshore Ireland. Petroleum Affairs Division, Dublin.

Patton, T.L., Moustafa, A.R., Nelson, R.A., Abdine, S.A., 1994. Tectonic evolution and structural setting of the Suez rift. In: Landon, S.M. (Ed.), Interior Rift Basins. American Association of Petroleum Geologists, pp. 9-55.
Péron-Pinvidic, G., Manatschal, G., 2009. The final rifting evolution at deep magmapoor passive margins from Iberia-Newfoundland: a new point of view. Int. J. Earth Sci. 98 , 1581-1597.

Phillips Petroleum Company, 1982. Well Phillips Petroleum 26/30-1 Composite Log Phillips Petroleum Company, prepared by Armstrong, A.J. (in-house publication)

Phillips Petroleum Company, 1983. Phillips Petroleum 26/30-1 Final Well Report. Phillips Petroleum Company, (in-house publication).

Prada, M., Watremez, L., Chen, C., O'Reilly, B.M., Minshull, T.A., Reston, T.J., Shannon, P.M., Klaeschen, D., Wagner, G., Gaw, V., 2017. Crustal strain-dependent serpentinization in the Porcupine Basin, offshore Ireland. Earth Planet Sci. Lett. 474, 148-159.

Praeg, D., 2004. Diachronous Variscan late-orogenic collapse as a response to multiple detachments: a view from the internides in France to the foreland in the Irish Sea In: In: Wilson, M., Neumann, E.R., Timmerman, M.J., Heeremans, M., Larsen, B.T. (Eds.), Permo-carboniferous Magmatism and Rifting in Europe. Special Publications, vol. 223, The Geological Society, London, pp. 89-138.

Prosser, S., 1993. Rift-related linked depositional systems and their seismic expression. In: In: Williams, G.D., Dobb, A. (Eds.), Tectonics and Seismic Sequence Stratigraphy. Special Publications, vol. 71, The Geological Society, London, pp. 35-66.

Purser, B.H., Bosence, D.W.J., 1998. Sedimentation and Tectonics in Rift Basins Red Sea:Gulf of Aden. Chapman \& Hall, London.

Ravnås, R., Steel, R.J., 1998. Architecture of marine rift-basin successions. AAPG (Am. Assoc. Pet. Geol.) Bull. 82 (1), 110-146.

Reading, H.G., 2007. Sedimentary Environments: Processes, Facies and Stratigraphy, third ed. Blackwell Publishing.

Readman, P.W., O'Reilly, B.M., Shannon, P.M., Naylor, D., 2005. The deep structure of the Porcupine Basin, offshore Ireland, from gravity and magnetic studies. In: Doré, A.G., Vining, B.A. (Eds.), Petroleum Geology: North-West Europe and Global Perspectives Proceedings of the 6th Petroleum Geology Conference. The Geological Society, London, pp. 1047-1056.

Reston, T.J., Pennel, J., Stubenrauch, A., Walker, I., Perez-Gussinye, M., 2001. Detachment faulting, mantle serpentinization, and serpentinite-mud volcanism beneath the Porcupine Basin, southwest of Ireland. Geology 29, 587-590.

Reston, T.J., Pennel, J., Klaeshen, D., Stubenrauch, A., Walker, I., 2004. Extreme crusta thinning in the south Porcupine Basin and the nature of the Porcupine Median High implications for the formation of non-volcanic rifted margins. J. Geol. Soc. Lond. 161 783-798.

Riddihough, R.P., Max, M.D., 1976. A geological framework for the continental margin to the west of Ireland. Geol. J. 11, 109-120.

Rider, M.H., 1990. Gamma-ray log shape used as a facies indicator: critical analysis of an oversimplified methodology. In: Hurst, A., Lowell, M.A., Morton, A.C. (Eds.), Geological Applications of Wireline Logs. The Geological Society, London, pp. 27-37.

Roberts, D.G., Thompson, M., Mithchener, B., Hossack, J., Carmichael, S., Bjørnseth, H.M., 1999. Palaeozoic to Tertiary rift and basin dynamics : mid-Norway to the Bay of Biscay - a new context for hydrocarbon prospectivity in the deep water frontier. In: Fleet, A.J., Boldy, S.A.R. (Eds.), Petroleum Geology of Northwest Europe: Proceedings of the 5th Conference. The Geological Society, London, pp. 7-40.

Robeson, D., Burnett, R.D., Clayton, G., 1988. The upper palaeozoic geology of the porcupine, erris and donegal basins, offshore Ireland. Ir. J. Earth Sci. 9, 153-175.

Robinson, K.W., Shannon, P.M., Young, D.G.G., 1981. The Fastnet Basin: an integrated analysis. In: Illing, L.G., Hobson, G.D. (Eds.), Petroleum Geology of the Continental Shelf of North-West Europe. Heyden and Son Ltd, London, pp. 444-454.

Savva, D., Pubellier, M., Franke, D., Chamot-Rooke, N., Meresse, F., Steuer, S., Auxiêtre, J.L., 2014. Different expressions of rifting on the South China Sea margins. In: In Franke, D., Li, C.F., Menier, D. (Eds.), Evolution, Structure, and Sedimentary Record of the South China Sea and Adjacent Basins. Marine and Petroleum Geology, Special Publication, vol. 58, pp. 579-598.

Shannon, P.M., Moore, J.G., Jacob, A.W.B., Makris, J., 1993. Cretaceous and Tertiary basin development west of Ireland. In: Parker, J.R. (Ed.), Petroleum Geology of Northwest Europe: Proceedings of the 4th Conference. The Geological Society, London, pp. 1057-1066.

Sharp, I.R., Gawthorpe, R.L., Armstrong, B., Underhill, J.R., 2000a. Propagation history and passive rotation of mesoscale normal faults: implications for synrift stratigraphic development. Basin Res. 12, 285-305.

Sharp, I.R., Gawthorpe, R.L., Underhill, J.R., Gupta, S., 2000b. Fault-propagation folding in extensional settings: examples of structural style and synrift sedimentary response from the Suez rift, Sinai, Egypt. GSA Bull. 112 (12), 1877-1899.

Sinclair, I.K., Shannon, P.M., Williams, B.P.J., Harker, S.D., Moore, J.G., 1994. Tectonic control on sedimentary evolution of three North Atlantic borderland Mesozoic basins. Basin Res. 6, 193-217.

Smith, L.K., White, R.S., Kusnir, N.J., iSIMM Team, 2005. Structure of the Hatton Basin and adjacent continental margin. In: Doré, A.G., Vining, B.A. (Eds.), Petroleum Geology: North-West Europe and Global Perspectives - Proceedings of the 6th Petroleum Geology Conference. The Geological Society, London, pp. 947-956.

Soper, N.J., Ryan, P.D., Dewey, J.F., 1999. Age of the grampian orogeny in Scotland and Ireland. J. Geol. Soc. Lond. 156, 1231-2136.

Srivastava, S.P., Verhoef, J., 1992. Evolution of Mesozoic sedimentary basins around the North Central Atlantic: a preliminary plate kinematic solution. In: In: Parnell, J. (Ed.), Basins on the Atlantic Seaboard: Petroleum Geology, Sedimentology and Basin Evolution. Special Publications, vol. 62, The Geological Society, London, pp. 397-420. 
Stampfli, G.M., Borel, G.D., 2002. A plate tectonic model for the Paleozoic and Mesozoic constrained by dynamic plate boundaries and restored synthetic oceanic isochrons. Earth Planet Sci. Lett. 196, 17-33.

Stampfli, G.M., von Raumer, J.F., Borel, G.D., 2002. Paleozoic evolution of pre-Variscan terranes: from Gondwana to the Variscan collision. In: Martínez Catalán, J.R., Hatcher, R.D.J., Arenas, R., Díaz García, F. (Eds.), Variscan-appalachian Dynamics: the Building of the Late Paleozoic Basement. Geological Society of America Boulder, Colorado, pp. 263-280.

Statoil, 1997. Well Statoil 26/28-A1 Composite Log. Statoil, prepared by McKibbin, M. (in-house publication).

Stoker, M.S., Stewart, M.A., Shannon, P.M., Bjerager, M., Nielsen, T., Blischke, A., Hjelstuen, B.O., Gaina, C., McDermott, K., Ólavsdóttir, J., 2017. An overview of the upper palaeozoic-mesozoic stratigraphy of the NE atlantic region. In: In: Péron-Pinvidic, G., Hopper, J.R., Stoker, M.S., Gaina, C., Doornenbal, J.C., Funck, T., Arting, U.E. (Eds.), The NE Atlantic Region: a Reappraisal of Crustal Structure, Tectonostratigraphy and Magmatic Evolution. Special Publications, vol. 447, The Geological Society, London, pp. 11-68.

Štolfová, K., Shannon, P.M., 2009. Permo-Triassic development from Ireland to Norway: basin architecture and regional controls. Geol. J. 44 (6), 652-676.

Tankard, A.J., Balkwill, H.R., 1989. Extensional tectonics and stratigraphy of The north atlantic margin: introduction. In: Tankard, A.J., Balkwill, H.R. (Eds.), Extensional Tectonics and Stratigraphy of the North Atlantic Margins. AAPG and Canadian Geological Foundation, Tulsa, pp. 1-6.

Tate, M.P., 1993. Structural framework and tectono-stratigraphic evolution of the Porcupine Seabight Basin, offshore western Ireland. Mar. Petrol. Geol. 10, 95-123.

Tate, M., Dobson, M.R., 1989a. Late Permian to early Mesozoic rifting and sedimentation offshore NW Ireland. Mar. Petrol. Geol. 6, 49-59.

Tate, M., Dobson, M.R., 1989b. Syn- and post-rift igneous activity in the Porcupine Seabight Basin and adjacent continental margin W of Ireland. In: In: Morton, A.C., Parson, L.M. (Eds.), Early Tertiary Volcanism and the Opening of the NE Atlantic. Special Publications, vol. 39, The Geological Society, London, pp. 309-334.
Tate, M., White, N., Conroy, J.J., 1993. Lithospheric extention and magmatism in the Porcupine basin west of Ireland. J. Geol. Res. 98 (B8), 13905-13923.

Tugend, J., Manatschal, G., Kusznir, N.J., 2015. Spatial and temporal evolution of hyperextended rift systems: implication for the nature, kinematics, and timing of the Iberian-European plate boundary. Geology 43, 15-18.

Tyrrell, S., Haughton, P.D.W., Daly, J.S., 2007. Drainage reorganization during breakup of Pangea revealed by in-situ $\mathrm{Pb}$ isotopic analysis of detrital K-feldspar. Geol. Soc. Am. 35 (11), 971-974.

Watremez, L., Prada, M., Minshull, T., O'Reilly, B., Chen, C., Reston, T., Shannon, P., Wagner, G., Gaw, V., Klaeschen, D., Edwards, R., 2016. Deep structure of the Porcupine Basin from wide-angle seismic data. In: Bowman, M., Levell, B. (Eds.), Petroleum Geology of NW Europe: 50 Years of Learning - Proceedings of the 8th Petroleum Geology Conference.

White, N., Tate, M., Conroy, J.J., 1992. Lithospheric stretching in the Porcupine basin, west of Ireland. In: In: Parnell, J. (Ed.), Basins on the Atlantic Seaboard: Petroleum Geology, Sedimentology and Basin Evolution. Special Publications, vol. 62, The Geological Society, London, pp. 327-349.

Williams, B.P.J., Shannon, P.M., Sinclair, I.K., 1999. Comparative Jurassic and cretaceous tectono-stratigraphy and reservoir development in the Jeanne d'Arc and porcupine basins. In: Fleet, A.J., Boldy, S.A.R. (Eds.), Petroleum Geology of Northwest Europe: Proceedings of the 5th Conference. The Geological Society, London, pp. 487-499.

Worthington, R.P., Walsh, J.J., 2011. Structure of Lower Carboniferous basins of NW Ireland, and its implications for structural inheritance and Cenozoic faulting. J. Struct. Geol. 33 (8), 1285-1299.

Young, D.G.G., Bailey, R.J., 1974. An interpretation of some magnetic data off the west coast of Ireland. Geol. J. 9, 137-146.

Ziegler, P.A., 1988. Evolution of the Arctic-North Atlantic and the Western Tethys, first ed. AAPG, Boulder.

Ziegler, P.A., 1990. Geological Atlas of Western and Central Europe, first ed. Shell Internat. Petrol. Mij. and The Geological Society, London. 